\title{
1 Accelerating retail supply chain performance against pandemic \\ 2 disruption: Adopting resilient strategies to mitigate the long-term \\ 3 effects
}

4 Manu Sharma, Sunil Luthra, Sudhanshu Joshi, Anil Kumar

5 Purpose: COVID-19 has disrupted global supply chains, revealing dreadful gaps and

6 exposing vulnerabilities. Retailers are challenged to tackle risks and organise themselves to

7 fit into the 'new normal' scenario. This global outbreak has established a volatile

8 environment for supply chains; it has raised the question of survival in the market, forcing

9 organisations to rethink resilient strategies to be adopted for the post pandemic situation to

10 mitigate the long-term effects of this virus. This study explores the priorities for Retail

11 Supply Chains (RSCs) to align their business operations and strategies for the post pandemic 12 world.

13 Design/methodology/approach: This study has utilised integrated Full Consistency Model 14 (FUCOM) - Best Worst Method (BWM) methods for assessment of RSCs to enhance their business performance irrespective of pandemic disruptions. The FUCOM has been employed

16 to identify the priorities of determinants enhancing business performance, whereas RSC

17 strategies are evaluated using the BWM method.

18 Finding: The current study identifies 'Collaboration Efficiency' as the main criterion for 19 accelerating the performance of RSCs in a dynamic social environment. Also, the study 20 concludes that 'Order Fulfilment' and 'Digital RSCs' are the most appropriate resilient 21 business strategies to mitigate the long-term effects.

22 Research limitations/implications: Supply-demand balancing is a challenging task at the 23 moment, but highly significant for the future. The pandemic disruptions have placed intense 24 pressure on retailers to deliver products as per consumers' changing behaviours towards the 25 purchase of essentials and other products. Hence, 'Order Fulfilment' and 'Digitisation" 26 strategies should be adopted for meeting customer requirements and to ensure sustainability 27 in the post pandemic business world.

28 Originality/value: This work sets out a comprehensive framework which will be helpful for 29 accelerating RSCs performance against pandemic disruption by adopting resilient strategies 30 to mitigate the long-term effects.

31 Keywords: COVID-19; Dynamic social environment; Digitisation; Resilient retail supply 32 chains; Pandemic disruption; Performance; Mitigating risk. 


\section{Introduction}

35 The COVID-19 crisis has caused huge disruption, affecting global supply chains resulting in 36 a dearth of accessibility to markets, materials; most significantly, staff have suffered 37 physically, socially and financially. Since February 2020, world trade has been badly affected 38 (WTO, 2020). New regulations, changing consumer preferences and restricted working have 39 forced stakeholders to manage their Supply Chains (SCs) more effectively (Cohen, 2020).

40 The pandemic has short and long-term effects on Retail Supply Chains (RSCs); organisations 41 therefore need to find ways to survive and function in this situation irrespective of the 42 increasing rate of coronavirus spread. The pandemic has shown that global enterprises were 43 not prepared for such an event and did not have any planning for recovery in this situation 44 (Sarkis et al., 2020). Inadequate SCs with high numbers of intermediaries and lack of 45 information management have been the major issues contributing to the failure to cope with 46 the pandemic disruption (Sharma et al., 2020). In the highly disrupted environment, RSCs 47 need to have dynamic and resilient strategies to tackle the impact of coronavirus outbreaks.

48 Retailers have to enhance their performance to overcome financial losses and focus on 49 readiness for the post pandemic situation. This will be achieved by collaborative working 50 among the RSC partners. Due to the global pandemic, RSC cash flows are badly disrupted 51 and need immediate supply-demand balancing. Thus, to enhance current business

52 performance and achieve sustainability in the post-pandemic environment, enterprises need to

53 build resilient RSCs through their operational and information management capabilities to 54 follow consumer trends and technological advancements at a faster rate. Effective 55 collaboration will reduce cost and enhance efficiency of the business (Dahlmann and 56 Roehrich, 2019; Roggeveen and Sethuraman, 2020). Existing literature has shown that 57 enterprises have implemented several strategies for managing disruptions such as stockpiling, 58 diversification, crediting back up suppliers, emergency sourcing, buffer inventory, reserve 59 capacity, flexibility and collaborative strategies (Chowdhury et al., 2020). All these strategies 60 make SCs of the enterprises resilient, but COVID-19 is a unique type of disruption that has 61 changed consumer living conditions and their preferences radically. Disruption is not only 62 limited to consumers, it has changed the entire SC sourcing, procuring, manufacturing and 63 delivering systems. Thus, enterprises need to implement various strategies that should 64 appropriately fulfil the needs and wants of stakeholders during the pandemic and prepare 65 them for post pandemic conditions. The fluctuating demand and supply practices need to be 66 strengthened with advanced digital technologies, information management and data analytics 67 during and post COVID-19 for appropriate decision-making (Cao and Duan, 2017; Lohmer 
and Lasch, 2020). The COVID-19 situation is an indication of a new world where everyday business includes a shift to e-commerce, contact lease delivery, click and collect systems and order fulfilment on time. The adoption of business strategies such as optimisation, digitisation, order-fulfilment, diversification, omni-channel marketing etc. in a dynamic environment will definitely help organisations to develop resilient supply chains for the 'new normal' situation. The organisations are adopting reactive strategies to survive and sustain during this pandemic but this will not work in the long term. A successful company will have to redesign its SC structure, network and dependencies to become proactive for the uncertain and unpredictable future to be faced.

The retail sector contribution to GDP is $10 \%$ with a $8 \%$ contribution to overall employment. The market size of retail is USD 950 billion (2018-2019) and stands fifth largest in the global market. The retail industry in India is no exception. The pandemic disruption has decimated the retail industry; since late April, the retail trade has fallen to 15 percent. SCs involved in the sale of essential goods are also bearing losses as they are not able to sell other merchandise (Roggeveen and Sethuraman, 2020). The major segments contributing to GDP are household and personal care (50\%), healthcare $(31 \%)$ and food beverages (19\%). Moreover, there is an upsurge in the demand in each of the major segments of the market as an outcome of coronavirus outbreaks. The effect of this pandemic is visible on all industries including retail, IT, durables and others (Mckinsey, 2020). The pandemic effect can be clearly seen in the declining GDP of India, the lowest in the last six years (KPMG, 2020). The key contributors to the country's GDP viz., private consumption, investment and external trade have been badly affected (MoSPI, 2020).

The pressure of managing business operations has been intensified due to the changing consumption patterns of customers in the dynamic environment. An increase in online sales of essential goods is disrupting the demand-supply a function of RSCs. COVID-19 has challenged the managers of RSCs to learn and act decisively during this situation. New business strategies need to be implemented as per the volatile social and economic environments. There is no control on the pandemic right now and, if all these issues remain unresolved, RSCs may face business failure post COVID-19 due to a lack of resilient business strategies. It is important to understand in which direction RSCs should evolve and what can be the possible solutions that can resolve these issues and may facilitate RSCs to deal with the pandemic.

00 The answer to these questions lies in the research objectives of this study. Firstly, 01 determinants are explored that may enhance the performance of RSCs irrespective of 
102 pandemic disruptions. An assessment of these determinants will impart insights that can be 103 used during COVID-19 to enhance the efficiency of business operations of RSCs; this may 104 also help with recovery in the post pandemic situation. Secondly, conducting comparative 105 analysis of current business strategies designed for RSCs will help decision-makers to take 106 immediate actions to ensure sustainability throughout COVID-19 and provide insights to 107 become resilient in a 'new normal' situation. Currently, RSCs are assessing the environment, 108 anticipating the demands and endeavouring to satisfy consumers through local suppliers. The 109 business alternatives available to RSCs - demand driven, data-driven systems etc. - are 110 important for enetrprises to become more viable, agile and resilient in future (Adivar et al., 111 2018; Albors-Garrigos, 2020; Sajjad et al., 2020). The following research objectives need to 112 be addressed.

$114 R$ R. To identify the most significant determinants that may accelerate the performance of 115 RSCs post COVID-19 to mitigate the long-term effects.

$116 \boldsymbol{R} 2$. To explore appropriate business strategies for RSC alternatives that may enhance the 117 business performance and develop resilience in the 'new normal' situation.

119 To understand the determinants and their impact on RSCs, a comprehensive review is 120 conducted. This study has applied an integrated Multi-Criteria Decision Making (MCDM) 121 approach i.e., Full Consistency Model (FUCOM - Best Worst Method (BWM). The 122 integration of FUCOM-BWM in a model provides better results compared to other methods 123 such as AHP, TOPSIS or SWARA (Stevic' and Brkovic', 2020). The main benefits of 124 FUCOM and BWM methods are the lesser and consistent pairwise comparisons that can be 125 made (Pamucar et al., 2018; Stevic' and Brkovic', 2020). The research contributions are as 126 follows:

127 - This study provides a critical evaluation of determinants that may accelerate the 128 performance of RSCs during and post pandemic COVID-19 to mitigate the long-term effects.

130 - The study findings can help organisations to adopt the most appropriate strategies for 131 developing resilient RSCs to survive and sustain in a 'new normal' era.

133 The paper is organised in 6 sections. Section 2 elaborates the literature on determinants and 134 business strategy alternatives. Section 3 defines the steps of FUCOM and BWM methods to 
135 be applied in this research. Section 4 explains the phases of the research framework followed

136 by a discussion of findings and their implications in Section 5. The conclusion of the study,

137 limitations and future directions of research are discussed in Section 6.

\section{Literature Review}

140 This section throws light on the key determinants of RSCs and the multiple business

141 strategies that may be helpful in developing resilient SCs during and post pandemic. The 142 contributions by the various authors in the area of RSCs and determinants to enhance the 143 efficiency of business operations and overall performance are elaborated in this section. The 144 various determinants that may accelerate the performance of RSCs are identified from 145 existing literature. The "Scopus" and "Web of Science" (WoS) databases were selected for 146 the search process. The keywords "Retail Supply Chains" OR "Supply chain strategies" OR 147 'Business Strategies" OR "Organisation performance" were searched. The type of document 148 "articles" was selected and the years "2010-2020" were chosen for exploration of the 149 literature related to the study. Based on the first search, 82 articles in WoS and 145 articles in 150 Scopus were found. A total of 171 articles were selected after discarding duplicates. Any 151 conference proceedings and papers were excluded from the search. The articles that were not 152 related to the study were deleted, resulting in a final total of 105 articles. After a thorough 153 reading of the abstracts, only 45 papers were finally selected. From the selected papers, 154 determinants of RSCs were identified. The process involved an expert in the field thoroughly 155 reading the description of each determinant and alternative detailed in the questionnaire; 156 these were then evaluated according to their significance in the acceleration of RSC 157 performance during and post COVID-19 (Appendix I-A and I-B).

\subsection{Determinants of Retail Supply Chains for Enhancing Business Performance}

161 With the emergence of multiple channels, the structure of RSCs has transformed from a 162 typical network consisting of supplier, original equipment manufacturers, distributors, retail 163 stores, retailers and end users (Adivar, 2019). Although the focal company is still the retailer, 164 the dominant process is the multiple touch-points for customers. The RSC is dependent on 165 the relationship developed with partners such as suppliers, buyers and customers. RSC 166 performance is based on partnership (Simchi-Levi et al., 2008; Obeng, 2019; Albors167 Garrigos, 2020). The partnership may include two or more members mutually contributing to 168 obtain competitive advantage through information management, collaboration or shared 
169 benefits (Choudhary, 2014; Brandenburg et al., 2019; Kabuye et al., 2019; Nguyen and 170 Harrison, 2019).

171 The critical factor for building inter-organisational relationships is inter-dependence between

172 the members. When one of the members does not fully control the supply chain, inter-

173 dependence happens (Kamalaldin et al., 2020; Parimi and Chakraborty, 2020). When trust is

174 present in inter-organisational relationships, it facilitates coordination and capabilities (Jap,

175 1999; Pankowska, 2019; Singh et al., 2019; Liu et al., 2020). Successful relationships among

176 RSC members are also maintained by long-term commitments (Li and Jiang, 2019). Prince et

177 al. (2019) and Chen et al. (2019) have revealed that information-sharing is the key

178 requirement for collaborative inter-organisational relationships, concluding that it develops

179 competitiveness in supply chains. Sometimes, benefits are not equally shared among partners.

180 Past studies have suggested that successful collaboration among RSC partners is based on 181 centralisation (Hughes et al., 2019). Close collaboration among RSC partners reduces risk 182 and uncertainty and thus acts as a support in a disruptive environment (Madsen and 183 Petermans, 2020). Collaboration in times of uncertainty enhances the performance of RSCs 184 by reducing a firm's cost, increasing cash flow and mitigating the bullwhip effect in retail 185 chains (Bozic and Kuppelwieser, 2019). The pandemic effect on SCs is visible in their forms, 186 alliances and changes in their organisational size in order to provide relief to affected 187 communities. The available resources and information management in humanitarian relief 188 operations play an important role in the inter-relationships of all RSC partners (Pankowska, 189 2019). But, due to the temporary status of relief operations, visibility becomes a complex 190 issue to be managed (Ivanov et al., 2019). Visibility of resources such as warehouse location 191 and supplies is important for RSCs to provide help to the beneficiaries.

192 Section 3.3 elaborates the details of the experts. The experts merged determinants under six 193 criteria - Collaboration efficiency $\left(\mathrm{C}_{1}\right)$; Partnership structure $\left(\mathrm{C}_{2}\right)$; Adoption of digital 194 technologies $\left(\mathrm{C}_{3}\right)$; Humanitarian relief operations $\left(\mathrm{C}_{4}\right)$; Operational and dynamic capabilities $195\left(\mathrm{C}_{5}\right)$; Information and communication quality $\left(\mathrm{C}_{6}\right)$. The final representation is shown in Table 1961.

197 Table 1: Determinants (Criteria) of RSCs for enhancing business performance

\begin{tabular}{l|l|l|}
\hline Criteria & Business performance Outcomes & References \\
\hline Collaboration & - Collaboration with suppliers in & $\begin{array}{l}\text { Holgado de Hollmann et } \\
\text { efficiency }\left(\mathrm{C}_{1}\right)\end{array}$ \\
& $\begin{array}{l}\text { anticipating the demand to enhance } \\
\text { al. (2015); Basso et al. }\end{array}$ \\
(Collaborative & with survival in the post pandemic & $\begin{array}{l}\text { (2019) Deep et an (2019); } \\
\text { Pahifar and }\end{array}$ \\
\hline
\end{tabular}




\begin{tabular}{|c|c|c|}
\hline $\begin{array}{l}\text { Planning, Forecasting } \\
\text { and replenishment, } \\
\text { Resource sharing, } \\
\text { Network resources, } \\
\text { Co-creation) }\end{array}$ & $\begin{array}{l}\text { situation. } \\
\text { - The resources commonly shared } \\
\text { such as data, information, knowledge } \\
\text { and plans etc. to enhance the } \\
\text { efficiency of each business operation. } \\
\text { - External sources provide strategic } \\
\text { opportunities to RSCs to take } \\
\text { specific actions. } \\
\text { - Collaborative innovation brings } \\
\text { value added products that may fulfil } \\
\text { the needs of customers during } \\
\text { difficult times. }\end{array}$ & $\begin{array}{l}\text { Shokouhyar (2019); Ryu } \\
\text { et al. (2019); Chtourou } \\
\text { Ben Amar and Ben. } \\
\text { (2019); Angulo-Baca et } \\
\text { al. (2020), Kamalaldin et } \\
\text { al. (2020); Parimi, and } \\
\text { Chakraborty (2020);); } \\
\text { Crick et al. (2020); Deep } \\
\text { et al. (2020). }\end{array}$ \\
\hline $\begin{array}{l}\text { Partnership } \\
\text { structure }\left(\mathrm{C}_{2}\right) \\
\text { (Including Flexibility, } \\
\text { Visibility, governance } \\
\text { structures) }\end{array}$ & $\begin{array}{l}\text { - The flexible structure of partnership } \\
\text { supports traceability and } \\
\text { transparency in RSCs. } \\
\text { - Product visibility increases supply } \\
\text { chain resilience during times of } \\
\text { uncertainty. } \\
\text { - Helps to enhance flexibility among } \\
\text { partners in RSCs. It supports retail } \\
\text { organisations to quickly respond to } \\
\text { the uncertain environment. }\end{array}$ & $\begin{array}{l}\text { Bstieler and Hemmert } \\
\text { (2015); Govindan and } \\
\text { Malomfalean (2019); Xu } \\
\text { and Jackson (2019); } \\
\text { Ivanov et al., (2019); } \\
\text { Ampe-N'DA et al } \\
\text { (2020); Kamalaldin et al. } \\
\text { (2020); Li et al. (2020); }\end{array}$ \\
\hline $\begin{array}{l}\text { Adoption of Digital } \\
\text { Technologies } \\
\left(\mathrm{C}_{3}\right)\end{array}$ & $\begin{array}{l}\text { - Artificial Intelligence (AI), IoT etc. } \\
\text { provide real time data monitoring } \\
\text { that aids in appropriate decision } \\
\text { making. } \\
\text { - Online order and delivery } \\
\text { management accelerates the order } \\
\text { fulfilment processes and enhances } \\
\text { efficiency. } \\
\text { - BDA provides insights for decision } \\
\text { making to deal with uncertain } \\
\text { conditions. } \\
\text {-Saves cost and time. }\end{array}$ & $\begin{array}{l}\text { Liu (2014); Griffith et al. } \\
\text { (2019); Chai and Ngai } \\
(2020)\end{array}$ \\
\hline $\begin{array}{l}\text { Humanitarian relief } \\
\text { operations }\left(\mathrm{C}_{4}\right)\end{array}$ & $\begin{array}{l}\text { - Emergent stock is held by } \\
\text { companies; severe problems to } \\
\text { communities will result if stocks run } \\
\text { out. } \\
\text { - Reducing product complexity and } \\
\text { delivering product flexibility results } \\
\text { in reducing cost. } \\
\text { - More options to make a delivery } \\
\text { help retailer to avoid flow }\end{array}$ & $\begin{array}{l}\text { Balcik et al. (2010); Day } \\
\text { (2014); Çelik, (2016); } \\
\text { L'Hermitte et al. (2016); } \\
\text { Ransikarbum and Mason } \\
\text { (2016); Kamalaldin et } \\
\text { al. (2020) }\end{array}$ \\
\hline
\end{tabular}




\begin{tabular}{|c|c|c|}
\hline & disruptions. & \\
\hline $\begin{array}{l}\text { Operational and } \\
\text { dynamic capabilities } \\
\left(\mathrm{C}_{5}\right)\end{array}$ & $\begin{array}{l}\text { - Capabilities develop competitive } \\
\text { advantages for retail firms. Re- } \\
\text { designing to mitigate risk and } \\
\text { disruption. } \\
\text { - Developing competitive advantage } \\
\text { for RSCs to act as differentiator for } \\
\text { the long run. }\end{array}$ & $\begin{array}{l}\text { Frasquet et al. (2013); } \\
\text { Gupta (2014); Beske et } \\
\text { al. (2014) Liu et al. } \\
(2014) \text {; Chen et al. } \\
(2017) \text {, Feizabadi et al. } \\
(2019)\end{array}$ \\
\hline $\begin{array}{l}\text { Information and } \\
\text { Communication } \\
\text { quality }\left(\mathrm{C}_{6}\right)\end{array}$ & 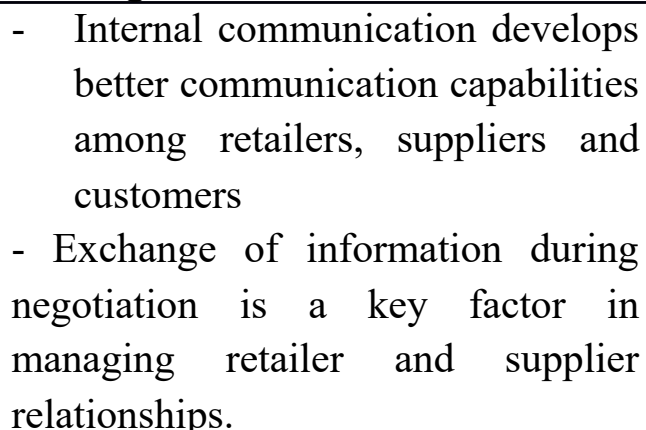 & 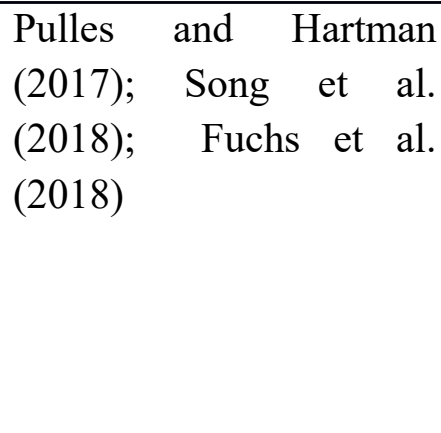 \\
\hline
\end{tabular}

\subsection{Retail Supply Chain Business Strategies}

200 Due to the complexities of the dynamic environment, RCSs are operating with different

201 strategies to meet the changing requirements of consumers with growing service levels of

202 their expectations. Collaboration, digital technologies, humanitarian logistics operations,

203 partnerships, information sharing and operational capabilities facilitate a better demand and

204 balance supply, consequently reducing cost and buffer stock while generating a higher level

205 of satisfaction for customers (Pereira and Frazzon, 2020). These determinants provide the

206 facility to adopt business strategies such as order fulfilment, digitisation, demand forecasting

207 etc. that is necessary to become resilient in a post pandemic situation. Intense pressure has

208 been placed on retailers engaged in selling essentials to provide value added services during

209 COVID-19. Due to the volatile demand during the pandemic, retailers are shifting from a

210 traditional model to order fulfilment, demand-driven, data driven and omni-channel models

211 for managing RSCs (Choi et al., 2020; Chai and Ngai, 2020; Ishfaq and Bajwa 2019; Naik

212 and Suresh, 2018). Retailers are using outsourcing companies to deliver their products and

213 collaborate with local suppliers to fulfil the demands of consumers during this pandemic

214 (Baharmand et al. (2019). Retail chains such as Big Bazaar Spencer, Grofers and many others

215 are utilising digital and non-digital forms; local retail chains are also trying to develop their

216 reach with both platforms.

217 RSCs are currently focusing on value-added areas to fight COVID-19; examples of this are in 218 optimisation, omni-channel supply chains, handling volatile demand, diversified supply 
219 chains, order fulfilment, financial stability and adapting hybrid channels (Mckinsey, 2020).

220 This study analyses current business strategies adopted by retail organisations with hybrid

221 channels to enhance their business performance and achieve sustainability in the future.

222 These strategies need to be compared with each other to identify the most suitable strategy

223 that may help RSCs to develop, face up to the pandemic environment and survive in a 'new

224 normal' market. The detailed business strategies adopted by RSCs are given in Table 2 .

225 Table 2: Business strategy (alternatives) for enhancing performance of RSCs and developing

226 resilience during and post pandemic

\begin{tabular}{|c|c|c|}
\hline RSCs & ce outcomes & Refe \\
\hline $\begin{array}{l}\text { Digitisation strategy } \\
\left(\mathrm{BS}_{1}\right)\end{array}$ & $\begin{array}{l}\text { E-commerce retailers are using digital } \\
\text { technologies to provide customer services } \\
\text { online and handle multiple requests at one } \\
\text { time. }\end{array}$ & $\begin{array}{l}\text { Day and } \\
\text { Schoemaker (2016); } \\
\text { Ivanov et al. (2018) }\end{array}$ \\
\hline $\begin{array}{l}\text { Omni-channel strategy } \\
\left(\mathrm{BS}_{2}\right)\end{array}$ & $\begin{array}{l}\text { Omni-channel supply chains provide one- } \\
\text { touch integration across all channels to } \\
\text { deliver unified experience. }\end{array}$ & $\begin{array}{l}\text { Mena et al. (2016); } \\
\text { Saghiri et al. } \\
\text { (2017); }\end{array}$ \\
\hline 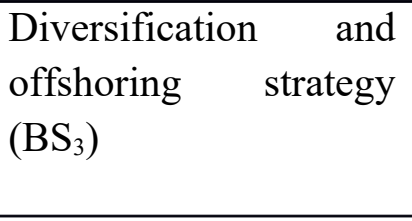 & $\begin{array}{l}\text { Retailers are extending the portfolio of } \\
\text { services to include core and non-core } \\
\text { services. Retailers are outsourcing services } \\
\text { by collaborating with external partners. }\end{array}$ & $\begin{array}{l}\text { Liu et al. (2010); } \\
\text { Baharmand et al. } \\
(2019)\end{array}$ \\
\hline $\begin{array}{l}\text { Order fulfilment and } \\
\text { optimisation strategy } \\
\left(\mathrm{BS}_{4}\right)\end{array}$ & $\begin{array}{l}\text { Retailers are collaborating with local } \\
\text { suppliers/partners for order fulfilment. }\end{array}$ & $\begin{array}{l}\text { Holweg and Helo } \\
\text { (2014); Rao et al. } \\
\text { (2011); Ishfaq and } \\
\text { Bajwa (2019) }\end{array}$ \\
\hline $\begin{array}{ll}\text { Inventory } & \text { control } \\
\text { strategy }\left(\mathrm{BS}_{5}\right) & \end{array}$ & $\begin{array}{l}\text { Essential supplies retailers are facing } \\
\text { unprecedented spikes in demand. The ability } \\
\text { to anticipate demand has become much more } \\
\text { significant. Demand forecasting and } \\
\text { inventory control need to be considered to } \\
\text { prevent stock-out situations. }\end{array}$ & $\begin{array}{l}\text { Verdouw et al. } \\
(2010) \text {; Mendes et } \\
\text { al. (2016); Chi et al. } \\
(2020)\end{array}$ \\
\hline $\begin{array}{l}\text { Distribution network } \\
\text { strategies }\left(\mathrm{BS}_{6}\right)\end{array}$ & $\begin{array}{l}\text { Retailers are extending their distribution } \\
\text { networks to meet demands of customers and } \\
\text { enhance their survivability. }\end{array}$ & $\begin{array}{lrr}\text { Hingley } & \text { et } & \text { al. } \\
(2015) ; & \text { Naik and } \\
\text { Suresh, }(2018) & \end{array}$ \\
\hline $\begin{array}{l}\text { Revenue management } \\
\text { strategy }\left(\mathrm{BS}_{7}\right)\end{array}$ & $\begin{array}{l}\text { Retailers are looking at overall financial } \\
\text { stability in the context of different scenarios. } \\
\text { Retailers are closely looking at liquidity and } \\
\text { working capital }\end{array}$ & $\begin{array}{lr}\text { Ivanov et al. (2010); } \\
\text { Selviaridis and } \\
\text { Norrman (2014); } \\
\text { Martin } \\
\text { Hofmann, (2019) }\end{array}$ \\
\hline $\begin{array}{l}\text { Customer relationship } \\
\text { management }(\mathrm{CRM}) \\
\text { strategy }\left(\mathrm{BS}_{8}\right)\end{array}$ & $\begin{array}{l}\text { Retailers are finding ways to build and } \\
\text { maintain trust among consumers. }\end{array}$ & $\begin{array}{l}\text { Sukati et al (2012); } \\
\text { Li et al. (2019) }\end{array}$ \\
\hline
\end{tabular}




\begin{tabular}{l|l|l}
\hline $\begin{array}{l}\text { Dynamic pricing } \\
\text { strategy }\left(\mathrm{BS}_{9}\right)\end{array}$ & $\begin{array}{l}\text { Due to limited supply, there is an increase in } \\
\text { list pricing by CPC companies. Continuous } \\
\text { evaluation of demand and supply data, } \\
\text { coupled with sentiment analysis can help in } \\
\text { effective pricing. }\end{array}$ & $\begin{array}{l}\text { Jamali and Rasti- } \\
\text { Barzoki (2018); Li } \\
\text { et al. (2019) }\end{array}$ \\
\hline
\end{tabular}

228 While RSCs continuously work to increase their productivity, profits, develop competitive 229 advantages, build customer relations and fulfil orders, the dynamic environment involving 230 various factors decides the overall priorities of retail firms (Youn et al., 2017). Table 2 231 elaborates on different types of business strategies of RSCs that currently exist in literature.

232 But during COVID-19, those RSCs that will be more effective and suitable still need to be 233 identified and assessed.

\subsection{Research Gaps}

236 Researchers have discussed retailer-centric and supply chain issues, challenges, capabilities 237 and the role of determinants such as information sharing (Gandhi, 2016; Sener et al., 2019; 238 Cragg and McNamara (2018); Collaboration (Panahifar et al., 2019); partnership structures 239 (Ampe-N'DA et al., 2020; Sorkun et al., 2020), performance measurement (Iqbal et al., 240 2019;Álvarez-Rodríguez et al., 2020a), efficiency (Ekinci and Baykasoğlu, 2019; Álvarez-

241 Rodríguez et al., 2020b), logistics (Abushaikha et al., 2020), managing risk (Wang et al., 242 2020), coordination (Wankmüller and Reiner, 2020), corporate responsibility and sustainable 243 SCs (Carbone et al., 2012; Fantazy and Tipu, 2019). Researchers have also assessed RSCs 244 and identified the factors responsible for their success. The different types of RSCs discussed 245 previously are omni-channel RSCs (Saghiri et al., 2017), optimisation RSCs (Fares and 246 Lebbar, 2019), order fulfilment and delivery RSCs (Hübner et al., 2016; Sillanpää and Liesiö, 247 2018; Peinkofer et al., 2019). The digital advancement affecting RSCs has also been analysed

248 by a few researchers, looking at its adaptability to the dynamic environment (Gustafsson et 249 al., 2019; Iftikhar and khan, 2020). The unpredicted demand and forecasting in the changing 250 environment is also significant for RSCs i.e. demand driven RSCs (Hofmann and 251 Rutschmann, 2018; Sandberg and Jafari, 2018), dynamic business modelling for 252 sustainability (Ansari and Kant 2017; Cosenz et al., 2020), reverse supply chains (Frei et al., 253 2020).

254 Table 3: Main contributions

\begin{tabular}{|l|l|l|l|}
\hline Author(s) & Objective of the study & Key determinant(s) & Industry \\
\hline Sener et al. (2019) & Measuring the role of & Information usage & Food Retail \\
\hline
\end{tabular}




\begin{tabular}{|c|c|c|c|}
\hline & $\begin{array}{l}\text { information usage } \\
\text { between information } \\
\text { sharing and operational } \\
\text { efficiency }\end{array}$ & & organisations \\
\hline $\begin{array}{l}\text { Kamalaldin et al. } \\
(2020)\end{array}$ & $\begin{array}{l}\text { Examining customer } \\
\text { relationships engaged } \\
\text { in digital servitization }\end{array}$ & $\begin{array}{l}\text { Collaboration; Partnership; } \\
\text { Servitizaions; Digitization }\end{array}$ & $\begin{array}{l}\text { Retail } \\
\text { Organisations }\end{array}$ \\
\hline $\begin{array}{l}\text { Parimi, and } \\
\text { Chakraborty } \\
(2020)\end{array}$ & $\begin{array}{l}\text { To find a link between } \\
\text { green SCM and co- } \\
\text { creation }\end{array}$ & $\begin{array}{ll}\text { Co-creation } & \text { and } \\
\text { Sustainability } & \end{array}$ & $\begin{array}{l}\text { Manufacturing } \\
\text { organisations }\end{array}$ \\
\hline $\begin{array}{l}\text { Sorkun et al. } \\
(2020) ;\end{array}$ & $\begin{array}{l}\text { Revealing a } \\
\text { relationship between } \\
\text { omni-channel } \\
\text { capability and } \\
\text { customer satisfaction }\end{array}$ & $\begin{array}{l}\text { Omni-channel capability, } \\
\text { flexibility }\end{array}$ & $\begin{array}{l}\text { Online and } \\
\text { physical } \\
\text { organisations; }\end{array}$ \\
\hline $\begin{array}{l}\text { Saghiri et al. } \\
(2017)\end{array}$ & $\begin{array}{l}\text { To develop a three- } \\
\text { dimensional } \\
\text { framework for omni- } \\
\text { channel }\end{array}$ & hannel strategy & $\begin{array}{l}\text { Retail supply } \\
\text { chains }\end{array}$ \\
\hline $\begin{array}{l}\text { Álvarez-Rodríguez } \\
\text { et al. }(2020)\end{array}$ & $\begin{array}{l}\text { Evaluation of the } \\
\text { operational } \\
\text { performance of RSCs }\end{array}$ & $\begin{array}{l}\text { Sustainability-oriented } \\
\text { efficiency and Sustainability } \\
\text { benchmarking }\end{array}$ & $\begin{array}{l}\text { Retail supply } \\
\text { chains }\end{array}$ \\
\hline $\begin{array}{l}\text { Abushaikha et al. } \\
(2020)\end{array}$ & $\begin{array}{l}\text { Role of logistics in } \\
\text { RSCs performance }\end{array}$ & $\begin{array}{l}\text { Coordination in logistics, } \\
\text { Supply chain resiliency, } \\
\text { flexibility and knowledge } \\
\text { creation }\end{array}$ & $\begin{array}{l}\text { Retail logistics } \\
\text { organisations }\end{array}$ \\
\hline $\begin{array}{l}\text { Wang et al. } \\
(2020)\end{array}$ & $\begin{array}{l}\text { Developing for } \\
\text { framework chain } \\
\text { managing supply che } \\
\text { uncertainty and risk. }\end{array}$ & $\begin{array}{l}\text { Integrtation in supply chain, } \\
\text { Supply chain risk } \\
\text { management }\end{array}$ & $\begin{array}{l}\text { Pharmaceutical } \\
\text { organisations }\end{array}$ \\
\hline $\begin{array}{l}\text { Fares and Lebbar } \\
(2019)\end{array}$ & $\begin{array}{l}\text { Analysis of the value } \\
\text { chains and identifying } \\
\text { solutions to improve } \\
\text { their productivity and } \\
\text { profit. }\end{array}$ & Optimization & $\begin{array}{l}\text { Fashion Retail } \\
\text { organisations }\end{array}$ \\
\hline Ishfaq and Bajwa & Assessing the impact & fulfilment; & Multi channel \\
\hline
\end{tabular}




\begin{tabular}{|c|c|c|c|}
\hline (2019) & $\begin{array}{l}\text { of online order } \\
\text { fulfilment }\end{array}$ & commerce & $\begin{array}{ll}\text { retail supply } \\
\text { chains }\end{array}$ \\
\hline $\begin{array}{l}\text { Hübner et al., } \\
(2016) ;\end{array}$ & $\begin{array}{l}\text { Building an effective } \\
\text { and efficient omni- } \\
\text { channel } \\
\text { (OC) } \\
\text { distribution system }\end{array}$ & $\begin{array}{lll}\text { Order fulfilment and } \\
\text { delivery }\end{array}$ & $\begin{array}{l}\text { Retail supply } \\
\text { chains }\end{array}$ \\
\hline $\begin{array}{l}\text { Peinkofer et al. } \\
(2019)\end{array}$ & $\begin{array}{l}\text { Current understanding } \\
\text { of the nuances of drop- } \\
\text { shipping operations }\end{array}$ & Order fulfilment & Supply chains \\
\hline $\begin{array}{l}\text { Sillanpää } \quad \text { and } \\
\text { Liesiö, (2018) }\end{array}$ & $\begin{array}{lr}\text { Modeling } & \text { consumer } \\
\text { demand } & \text { with } \\
\text { distributions } & \\
\end{array}$ & $\begin{array}{ll}\text { replenishment } & \text { order } \\
\text { forecasts } & \end{array}$ & $\begin{array}{l}\text { Retail } \\
\text { organisations }\end{array}$ \\
\hline $\begin{array}{l}\text { Gustafsson et al. } \\
(2019)\end{array}$ & $\begin{array}{l}\text { Exploring Digital } \\
\text { technologies adaptation } \\
\text { in } \quad \text { a dynamic } \\
\text { environment }\end{array}$ & $\begin{array}{l}\text { Demand forecasting; supply } \\
\text { chain performance; Data } \\
\text { analytics; technological } \\
\text { investment; Accuracy in } \\
\text { forecasting }\end{array}$ & $\begin{array}{l}\text { Retail supply } \\
\text { chains }\end{array}$ \\
\hline $\begin{array}{l}\text { Hofmann and } \\
\text { Rutschmann, } \\
(2018)\end{array}$ & $\begin{array}{l}\text { Measuring the role of } \\
\text { data analytics and } \\
\text { information } \\
\text { management }\end{array}$ & $\begin{array}{l}\text { Data analytics; Information } \\
\text { management }\end{array}$ & $\begin{array}{l}\text { Retail supply } \\
\text { chains }\end{array}$ \\
\hline $\begin{array}{ll}\text { Sandberg } & \text { and } \\
\text { Jafari (2018) } & \end{array}$ & $\begin{array}{lr}\text { Review of existing } \\
\text { research on } & \text { retail } \\
\text { supply } & \text { chain } \\
\text { responsiveness } & \\
\end{array}$ & $\begin{array}{l}\text { Retail supply chain } \\
\text { responsiveness }\end{array}$ & $\begin{array}{l}\text { Retail supply } \\
\text { chains }\end{array}$ \\
\hline $\begin{array}{lll}\text { Cosenz } & \text { et } & \text { al. } \\
(2020) & & \end{array}$ & $\begin{array}{lr}\text { A } & \text { conceptual } \\
\text { framework for business } \\
\text { modeling } \\
\text { sustainable } & \text { for } \\
\text { model } & \end{array}$ & $\begin{array}{l}\text { Dynamic business modeling } \\
\text { for sustainability; economic, } \\
\text { social and environmental } \\
\text { drivers for sustainable } \\
\text { development }\end{array}$ & $\begin{array}{l}\text { Retail supply } \\
\text { chains }\end{array}$ \\
\hline
\end{tabular}

256 The contributions shown in Table 3 has addressed the determinants independently but a

257 comprehensive study on the determinants that affect the performance of the retail 258 organisations during and post COVID and their SCs is still missing; this can help managers in 259 industry to mitigate the long-term effects. Some researchers have measured the performance 260 of RSCs but during COVID-19, how these RSCs are changing their functions and surviving 
modes to beat the pandemic disruption need to be analysed. The strategy that may be most suitable in a pandemic is explored in this study. Therefore, this study aims to bridge this gap and analyse the determinants for RSCs to showcase new insights to deal with COVID-19.

\section{Research Methodology}

The study has employed integrated FUCOM-BWM methods. The FUCOM method is employed to find out the weights of determinants of RSCs to enhance business performance whereas a BWM method is employed to select the most appropriate business strategy for RSCs to become resilient during and post pandemic.

For assessment of a range of factors, Analytic Hierarchy Process (AHP) has been widely used, but after the introduction of BWM, researchers have generally replaced AHP. In previous studies, it is integrated with Failure Mode and Effects Analysis (FMEA), Technique for Order of Preference by Similarity to Ideal Solution (TOPSIS) and other MCDM techniques. The FUCOM and BWM methods are more consistent than other MCDM methods such as AHP, Fuzzy AHP or TOPSIS; these methods eradicate the problem of redundancy of pairwise comparisons of criteria that exist in other subjective models for determining the weights of criteria. In recent years, BWM has significantly emerged as the most reliable MCDM method to provide relevant results for optimal decision-making. With the help of FUCOM and BWM methods, optimal weights are obtained with a minimum number of pairwise comparisons. Due to the small number of pairwise comparisons, inconsistencies are removed. These methods provide more reliable results compared to the AHP method; there is greater consistency in the results. Further, the BWM method includes reference comparisons implying the advantages of best criterion over all other criteria and advantages of such criteria over the worst criterion. This method is much simpler and more accurate. The details of the methods are discussed in the following sub-sections.

\subsection{Full Consistency Model (FUCOM)}

Pairwise comparisons are the basis of this method with validation of results by deviation from maximum consistency. This method compares a lesser number of criteria (only $n-1$ comparison), with an ability to validate results by defining the deviation from maximum consistency. This method has a subjective influence of decision makers on the computation of the final values of the weights of the criteria. This method has an advantage of minor deviations in the obtained values of weights of criteria from optimal values. This method also eradicates the problem of redundancy of pairwise comparisons of criteria that exist in other 
295 subjective models for determining weights of criteria (Pamucar et al., 2018; Stevic ' and 296 Brkovic', 2020). The steps of the FUCOM methods are:

298 Step 1: Ranking of criteria/sub-criteria by experts.

299 Step 2: Obtaining the vectors of the weight coefficients of criteria/sub-criteria.

300 Step 3: Defining the conditions of a non-linear optimisation model.

301 Condition 1: efficients of criteria is equal to the comparative significance among the 302 observed criteria; this can be calculated as $\left(W_{k} / W_{k+1}=\varphi_{k /(k+1)}\right)$

303 Condition 2: The value of the weight coefficients should satisfy the conditions of the mathematical transitivity; this can be calculated as $-\varphi_{\mathrm{k} /(\mathrm{k}+1)} \otimes \varphi_{(\mathrm{k}+1) /(\mathrm{k}+2)}=\varphi_{\mathrm{k} /(\mathrm{k}+2)}$.

Step 4: Defining a model to determine the final values of weight coefficients of evaluation 307 criteria.

Step 5: Computing the values of evaluation criteria/sub criteria $\left(\mathrm{w}_{1}, \mathrm{w}_{2}, \ldots, \mathrm{w}_{\mathrm{n}}\right)^{\mathrm{T}}$.

3.2 Best Worst Method (BWM)

313 This method helps decision-makers to take decisions more accurately as results of this 314 method are more consistent (Rezaei et al., 2016). The steps for this method are specified as 315 follows:

316 Step 1: Determine a set of decision criteria.

317 Step 2: Determine the Best (B), most important, and the Worst (W), least important, based on 318 expert opinion.

319 Step 3: Determine the preference of the best decision criterion (B) over all the decision 320 criteria using a 9-point scale. The result is a Best-to-Others (BO) vector as follows.

322 Where, $\mathrm{a}_{\mathrm{Bj}}$ represents the preference of $\mathrm{B}$ over $\mathrm{j}$ and $\mathrm{a}_{\mathrm{BB}}=1$

323 Step 4: Determine the preference of all decision criteria over the worst criteria (W) using a 324 9-point scale, which results in Others-to-Worst (OW) as follows.

Where, $\mathrm{a}_{\mathrm{jw}}$ represents the preference of $\mathrm{j}$ over $\mathrm{W}$ and $\mathrm{a}_{\mathrm{ww}}=1$ 
Step 5: Compute the optimal weights

329 The optimal weights should be determined so that maximum absolute differences for all $\mathrm{j}$ is 330 minimised, or equivalently.

332 for all $\mathrm{j}$ is minimised, or equivalently

333

336 , for all $j$

337 Problem (Eq. 1) is equal to the following linear problem

$\min \xi^{\mathrm{L}}$

, for all $j$

for all $j$

Eq. (2)

343 , for all $j$

344 By (Eq. 2), the optimal weights $\left(\mathrm{w}_{1}{ }^{*}, \mathrm{w}_{2}{ }^{*}, \ldots \mathrm{w}_{\mathrm{n}}{ }^{*}\right)$ and the $\xi^{\mathrm{L}_{*}}$ are obtained where $\xi^{\mathrm{L}_{*}}$ is the 345 consistency index; the values close to zero show a high level of consistency.

\subsection{Data Collection}

348 The study has involved experts from retail and supply chain industries operating in offline 349 and online formats in India. The experts include supply chain practitioners belonging to 350 different domains. The questionnaire (Appendix I-A and I-B) is shared online with the 351 experts after e-discussion on the determinants. The determinants are given in Table 1; case 352 locations and expert details are shown in Table 4.

353 Table 4: Details of case location and experts

\begin{tabular}{l|l|l|c|l|l}
\hline $\begin{array}{l}\text { RSC } \\
\text { No. }\end{array}$ & Retail Sector & $\begin{array}{l}\text { Physical } \\
\text { store } \\
\text { Online } \\
\text { store }\end{array}$ & $\begin{array}{l}\text { Number of } \\
\text { experts } \\
\text { undertaken }\end{array}$ & Area of experts & $\begin{array}{l}\text { Experience } \\
\text { of experts }\end{array}$ \\
\hline 1 & $\begin{array}{l}\text { Household } \\
\text { Personal care }\end{array}$ & Physical & 3 & Sales management & $\begin{array}{l}\text { More than } \\
10 \text { years }\end{array}$ \\
\hline 2 & Groceries and & Physical & 4 & Inventory & 8 years \\
\hline
\end{tabular}




\begin{tabular}{|c|c|c|c|c|c|}
\hline & Perishables & $\begin{array}{lr}\text { store } & + \\
\text { Online store }\end{array}$ & & management & \\
\hline 3 & Groceries & $\begin{array}{l}\text { Physical } \\
\text { store }+ \\
\text { Online store }\end{array}$ & 2 & Floor managers & 8 years \\
\hline 4 & $\begin{array}{l}\text { e-commerce } \\
\text { retailer }\end{array}$ & Online & 4 & $\begin{array}{l}\text { MIS/Information } \\
\text { systems/ Data analyst }\end{array}$ & 8 years \\
\hline 5 & $\begin{array}{l}\text { Sports } \\
\text { equipment } \\
\text { (Indoor) } \\
\end{array}$ & $\begin{array}{l}\text { Physical } \\
\text { store }+ \\
\text { Online store }\end{array}$ & 3 & $\begin{array}{l}\text { Inventory } \\
\text { management }\end{array}$ & 8 years \\
\hline 6 & Clothing & $\begin{array}{l}\text { Physical } \\
\text { store }+ \\
\text { Online store }\end{array}$ & 2 & $\begin{array}{l}\text { Customer Relation } \\
\text { Manager }\end{array}$ & $\begin{array}{l}\text { More than } \\
10 \text { years }\end{array}$ \\
\hline 7 & Healthcare & Physical & 4 & $\begin{array}{ll}\text { Medical } & \text { equipment } \\
\text { and } & \text { healthcare } \\
\text { products } & \end{array}$ & $\begin{array}{l}\text { More than } \\
10 \text { years }\end{array}$ \\
\hline
\end{tabular}

\section{4. Proposed Research Framework}

356 The research objectives are achieved through three phases including steps shown in figure 1.

357 During the first phase, the determinants that may affect the business performance of RSCs are

358 identified and analysed through FUCOM to compute their weights in phase second. The

359 experts/decision makers, on the basis of identified determinants, assess business strategies of

360 RSCs using a BWM method in phase three. Figure 1 illustrates the proposed research

361 framework. 

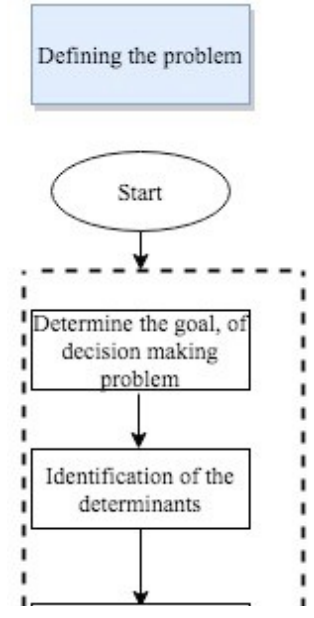

Computing weights for determinants through FUCOM

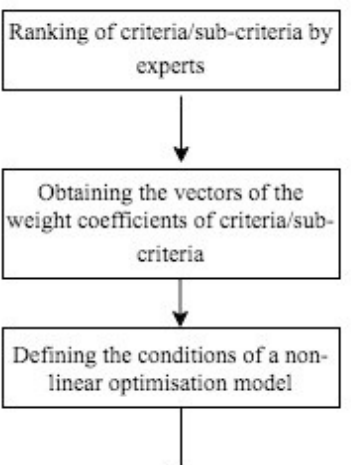

Figure 1: Proposed research framework

\subsection{An Application of Proposed Framework}

The focus of the study is to assess RSCs to enhance their performance during and post pandemic. The 22 experts (E1-

E22) belong to operations, inventory, sales and customer relations and IT departments of the retail firm. The selected managers are responsible for retail and supply chain management. The experience of the experts ranges from 5 to 15 years. These experts are aware of business strategies of RSCs and also the changing customer needs during the disruptive environment.

\subsubsection{Phase I: Determining weights of criteria using FUCOM method}

The order of criteria is obtained on the basis of decisions-makers/experts' preferences by comparing the criteria on a scale 1-9 (Appendix Table I-A). Experts arrange the criteria as per their importance in enhancing the business performance of RSCs. The responses by all experts are shown in Appendix II-A. The mean values of the experts' responses are shown in Table 5.

Table 5: Criteria comparisons (E1-E22)

\begin{tabular}{c|c|c|c|c|c|c}
\hline Experts & $\mathbf{C}_{\mathbf{1}}$ & $\mathbf{C}_{\mathbf{3}}$ & $\mathbf{C}_{\mathbf{4}}$ & $\mathbf{C}_{\mathbf{5}}$ & $\mathbf{C}_{\mathbf{2}}$ & $\mathbf{C}_{\mathbf{6}}$ \\
\hline & 1.0 & 2.69 & 3.24 & 4.11 & 5.94 & 7.34 \\
\hline
\end{tabular}

384 Based on the obtained priorities of the main criteria, comparative priorities are computed.

385 The obtained comparative values are as follows.

$386 \varphi \mathrm{C}_{1} / \mathrm{C}_{3}=2.69 / 1=2.69$;

$387 \varphi \mathrm{C}_{3} / \mathrm{C}_{4}=3.24 / 2.69=1.20$;

$388 \varphi \mathrm{C}_{4} / \mathrm{C}_{5}=4.11 / 3.24=1.27$;

$389 \varphi \mathrm{C}_{5} / \mathrm{C}_{2}=5.94 / 4.11=1.45$;

$390 \varphi \mathrm{C}_{2} / \mathrm{C}_{6}=7.34 / 5.94=1.24$

391 In the next step, the weight coefficient values are computed; two conditions must be fulfilled.

392 According to condition (1): 
394 According to condition (2):

$395 \varphi \mathrm{C}_{1} / \mathrm{C}_{4}=2.69 * 1.20=3.24 ; \varphi \mathrm{C}_{3} / \mathrm{C}_{5}=1.20 * 1.27=1.53 ; \varphi \mathrm{C}_{4} / \mathrm{C}_{2}=1.27 * 1.45=1.83 ;$

$396 \varphi \mathrm{C}_{5} / \mathrm{C}_{6}=1.45 * 1.24=1.79$

397

398 Hence, $w_{1} / w_{4}=3.24 ; w_{3} / w_{5}=1.53 ; w_{4} / w_{2}=1.83 ; w_{5} / w_{6}=1.79$

399

400 The final model from which the final values are obtained is:

$401 \min \chi$

402

403

404

405

406

407

408

409

410

411 Subsequently with the help of lingo software, the following model is obtained showing the

412 weights of the determinants as seen in Figure 2.

413

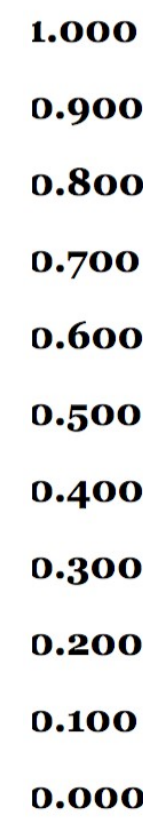

414

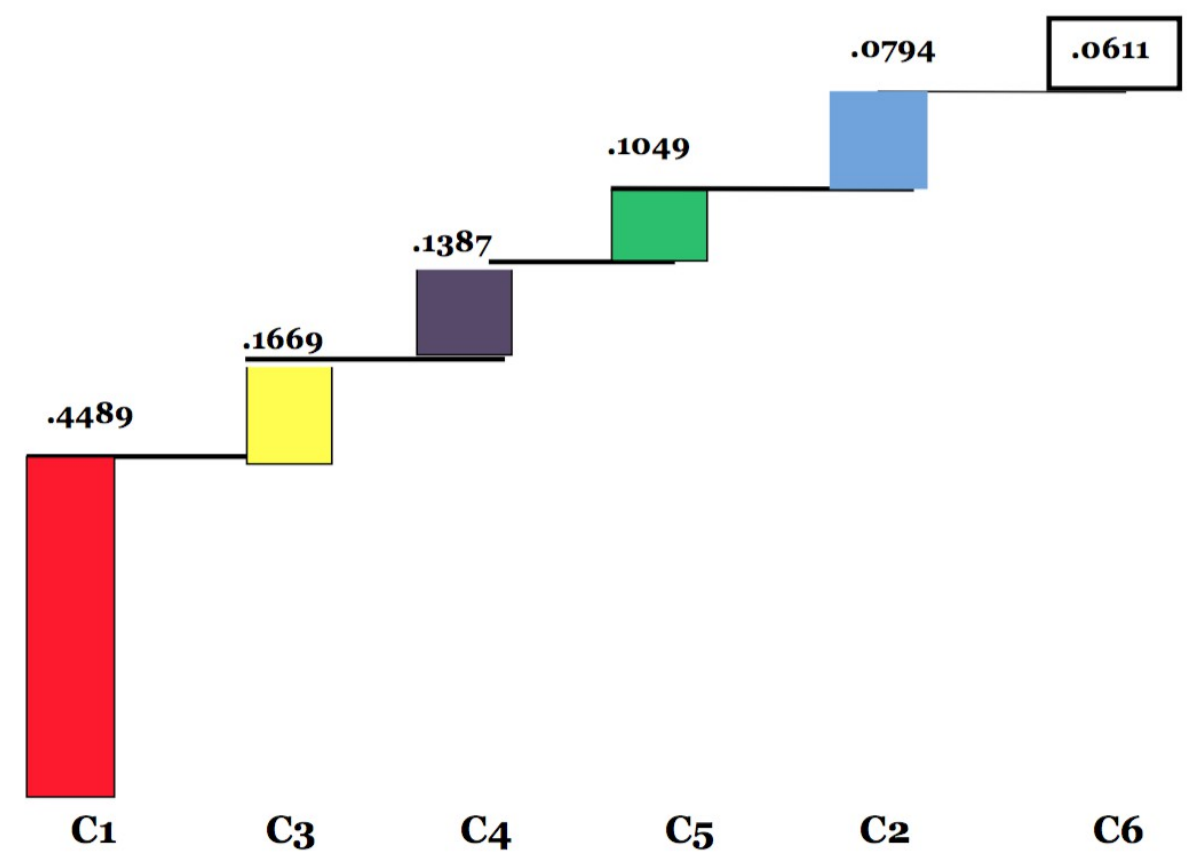


418 From Figure 2, it is clear that the most important criterion is $\mathrm{C}_{1}$ i.e., Collaboration 419 efficiency. It is accepted that during a pandemic, collaboration among partners of RSCs will 420 improve decision-making actions. The collaborative efforts of retailers, buyers and suppliers 421 will bring stability to RSCs and will support them post pandemic. This criterion is followed 422 by Adopting digital technology $\left(\mathrm{C}_{3}\right)$, Humanitarian relief operations $\left(\mathrm{C}_{4}\right)$ and Operational 423 and dynamic capabilities $\left(\mathrm{C}_{5}\right)$. The criteria Partnership structure $\left(\mathrm{C}_{2}\right)$ and Information and 424 communication quality $\left(\mathrm{C}_{6}\right)$ both have lower values, showing that these are less significant compared to other criteria in the current situation.

\subsubsection{Phase 2: Evaluating Business Strategy (alternatives) of RSCs using BWM method}

428 The steps discussed in Section 3.2 are again followed; an initial matrix is developed as shown in Table 6. The comparative evaluation of BSs is made with the BWM solver. The tables completed by the experts are shown (Appendix I-B, I-C, I-D).

431 Table 6: Best and Worst criteria (Experts E1-E22)

\begin{tabular}{c|c|c}
\hline Alternatives & Determines as Best by experts & Determined as Worst by experts \\
\hline $\mathrm{BS}_{1}$ & $\mathrm{E} 1, \mathrm{E} 13, \mathrm{E} 22$ & $\mathrm{E} 15$ \\
\hline $\mathrm{BS}_{2}$ & $\mathrm{E} 2, \mathrm{E} 6, \mathrm{E} 15$ & $\mathrm{E} 12, \mathrm{E} 9$ \\
\hline $\mathrm{BS}_{3}$ & $\mathrm{E} 4, \mathrm{E} 9$ & $\mathrm{E} 1, \mathrm{E} 13$ \\
\hline $\mathrm{BS}_{4}$ & $\mathrm{E} 18, \mathrm{E} 19, \mathrm{E} 21, \mathrm{E} 20$ & $\mathrm{E} 7, \mathrm{E} 10$ \\
\hline $\mathrm{BS}_{5}$ & $\mathrm{E} 3, \mathrm{E} 7, \mathrm{E} 10$ & $\mathrm{E} 19, \mathrm{E} 21, \mathrm{E} 20$ \\
\hline $\mathrm{BS}_{6}$ & $\mathrm{E} 11, \mathrm{E} 14$ & $\mathrm{E} 3, \mathrm{E} 16, \mathrm{E} 17$ \\
\hline $\mathrm{BS}_{7}$ & $\mathrm{E} 5, \mathrm{E} 8$ & $\mathrm{E} 5, \mathrm{E} 8, \mathrm{E} 22$ \\
\hline $\mathrm{BS}_{8}$ & $\mathrm{E} 16, \mathrm{E} 17$ & $\mathrm{E} 2, \mathrm{E} 6, \mathrm{E} 18$ \\
\hline $\mathrm{BS}_{9}$ & $\mathrm{E} 12$ &
\end{tabular}

433 All experts have ranked the RSCs using a 1-9 measurement scale. The BWM optimisation 434 model developed by Razaei (2016) is employed for computing. The weights of BSs from all 435 the experts are obtained through a BWM optimisation solver. The final weights are computed 436 through the geometric mean of all responses of the experts (Appendix II-B). The results of 437 the BWM optimisation are presented in Table 7.

438 Table 7: Ranking of business strategies alternatives

\begin{tabular}{c|c|c}
\hline Alternatives & Priorities & Ranking \\
\hline $\mathrm{BS}_{1}$ & 0.1247 & 2 \\
\hline $\mathrm{BS}_{2}$ & 0.0796 & 6 \\
\hline $\mathrm{BS}_{3}$ & 0.1028 & 4 \\
\hline
\end{tabular}




\begin{tabular}{c|c|c}
\hline $\mathrm{BS}_{4}$ & 0.1307 & 1 \\
\hline $\mathrm{BS}_{5}$ & 0.1118 & 3 \\
\hline $\mathrm{BS}_{6}$ & 0.0789 & 7 \\
\hline $\mathrm{BS}_{7}$ & 0.0830 & 5 \\
\hline $\mathrm{BS}_{8}$ & 0.0782 & 8 \\
\hline $\mathrm{BS}_{9}$ & 0.0739 & 9 \\
\hline
\end{tabular}

\section{Discussion of Findings}

The determinants of RSCs are listed on the basis of prominence value obtained by FUCOM; ranking of the appropriate retail chain alternatives is performed using the BWM application. This study is insightful for decision-makers to manage their SCs successfully during and post COVID-19. There is an urgent need for enterprises to enhance their business performance during and post COVID-19. The 'new normal' environment i.e., post COVID-19, will be challenging for retail organisations due to the changes in consumer purchasing patterns and the social environment. Thus, enterprises need to redesign their strategies and business operations to match the 'new normal' environmental needs.

Results show that collaboration efficiency $\left(C_{1}\right)$ is the most crucial determinant in enhancing business performance of RSCs during and post pandemic. Collaboration efficiency $\left(\mathrm{C}_{1}\right)$ has obtained the highest weight (0.4489) followed by Adoption of digital technologies $\left(\mathrm{C}_{3}\right)$ and Humanitarian operations $\left(\mathrm{C}_{4}\right)$. The main categories are ranked in order $\mathrm{C}_{1}>\mathrm{C}_{3}>\mathrm{C}_{4}>\mathrm{C}_{5}>\mathrm{C}_{2}>\mathrm{C}_{6}$ as shown in Figure 2. Collaboration between stakeholders has always been a significant factor in managing supply chains in order to develop a resilient system that fulfils the demands of customers appropriately in the changing environment (Ansari and Kant, 2017; Scholten and Schilder, 2015). Collaboration brings value added products and services to retail organisations who can adopt innovation strategies to cope with the way customers behave and shop (Balaji and Roy, 2017; Young et al., 2018).

During the pandemic, customer experience and perception are fully dependent on the retailers' and suppliers' contributions; co-creation for value added products and services will be able to build a path to enhance the performance of RSCs post pandemic. Stakeholders need to innovate and create value added products to ensure their survivability during and post COVID-19. Stakeholder needs and levels of satisfaction must be monitored during the pandemic; thus, determinants such as collaboration, efficiency and adoption of digital technology will be hugely important to RSCs to ensure value in their business operations. Added manufacturing, robotics, big data analytics (BDA) and IoT offer improved products and services to customers (Nasiri et al., 2020). Retail 4.0 is utilising these digital technologies 
468 and developing their supply chains to provide opportunities to develop value creation 469 (Gawankar et al., 2020). Digital technologies such as BDA provide information related to SC 470 functions in real time; this can reduce inventory costs and utilise resources optimally.

471 The other crucial determinant is Humanitarian relief operations; it obtained a weight of 472 0.1387. The pandemic has raised awareness levels in RSCs of the need to develop readiness 473 for dealing with uncertain situations like COVID-19. RSCs must understand and learn to 474 adopt the practices of keeping emergency stocks and product flexibility in order to survive 475 and sustain during uncertainty (Sajjad et al., 2020).

476 The selection of a suitable business strategy of RSCs to deal with the pandemic shows that 477 'Order fulfilment strategy' is the first choice of the experts. Order fulfilment $\left(\mathrm{BS}_{4}\right)(0.130)$ 478 has achieved the highest ranking in dealing with the pandemic, followed by Digitisation 479 strategy $\left(\mathrm{BS}_{1}\right)(0.124)$ and Inventory control strategy $\left(\mathrm{BS}_{5}\right)(0.111)$. As COVID-19 continues 480 to spread, retailers and suppliers have mutually stepped up their efforts to provide essentials 481 to customers. The study shows that RSCs are adopting order fulfilment, digitalisation strategy 482 and inventory control with a focus on high collaboration efficiency to fulfil the needs of 483 stakeholder during this time. In order to achieve this, RSCs are providing services to the 484 doorstep of customers as the majority of consumers are staying at home and shifting towards 485 e-commerce. This finding is in line with other research conducted during COVID-19 (Choi et 486 al., 2020; Pereira and Frazzon, 2020).

487 Order fulfilment can be appropriately met with real time information exchange between all 488 RSC partners. Currently, RSCs are trying to downsize their product lines, focusing on limited 489 orders to fulfil the demand on time and with full safety measures. RSCs are also making 490 efforts to deliver products within minimum time with the support of local partners. 491 Consumers have learned quickly how to overcome the environmental constraints imposed by 492 the government (Donthu and Gustafsson, 2020).

493 Digital technologies have offered a number of opportunities for retail organisations to attract 494 customers. The desire to remain, socialise and work at home is increasing day by day and 495 thus creates an opportunity for organisations to digitalise their SCs to reach customers. The 496 collaborative efforts of buyers and suppliers are much needed to strengthen relationships for 497 managing their digitised RSCs not only for its survival, but to develop the resilience needed 498 for sustainability post COVID-19 (Ivanov, 2020; Roggeveen and Sethuraman, 2020). Further, 499 the need of inventory planning, forecasting, demand and supply management have to adapt 500 dynamic systems that can update information in real time (Donthu and Gustafsson, 2020). 
501 RSCs are adopting the digital technologies needed for procuring, manufacturing and 502 delivering products; as a result, demand driven supply chains are emerging during the 503 pandemic (Ivanov, 2020). The third most preferred alternative is 'Inventory control strategy'. 504 Retailers and suppliers need to leverage powerful and analytical capabilities to predict and act 505 upon dynamic baselines during COVID-19. SC partners are conducting daily meetings to 506 secure a sufficient supply of high demand products. An inventory control strategy is also 507 needed as consumers are stockpiling essentials and health care products. Demand and supply 508 management has to be taken to local level to prevent stock out situations and lack of order 509 fulfilment.

511 Diversification and offshore strategies plus revenue management strategies must be managed 512 efficiently to ensure survival in a pandemic. Thus, retailers, worried about their current 513 flows, are devising ways to pay their bills over a prolonged period of time. RSCs are 514 predicting current and potential liquidity, working capital dynamics and making short-term 515 cash forecasts to deal with the existing financial crisis. Retailers are also thinking about their 516 key suppliers to assess their risk and indirect exposures while developing contingency plans 517 for surviving throughout the pandemic.

518 Organisations have to observe the demand for both short and long term and need

519 Collaborative Planning, Forecasting and Replenishment (CPFR) to strengthen SCs in 520 planning for the present and future scenarios. Currently, RSCs are facing low inventory levels 521 due to consumers stockpiling of essentials. In the post-COVID-19 environment the 522 transformation to collaborative planning along with a Digital Supply Chain (DSC) will be 523 required among RSC partners for their survival and stability. Today, organisations need 524 accurate, real-time information about inventories, logistics and in-transit movement to make 525 the best decisions in the 'new normal' environment.

\subsection{Contributions of the Research}

529 This study has explored the assessment of RSCs during an uncertain time. Rooted in the 530 business strategy literature, the Resource-Based View (RBV) explains and predicts how an 531 organisation can achieve sustainable competitive advantage through controlling the unique 532 resources and capabilities (Nandi et al., 2020). An organisation's resources refer to those 533 assets that enable the production and delivery of goods and serves (Grant 1991). The 534 organisation's capabilities refer to the resource utilisation; that how are resources in 
535 combination with the processes in the organisation are deployed to produce the desired output

536 (Liu et al., 2016). RBV theory is appropriate in explaining how the organisation can achieve

537 competitive advantage by transforming its unique resources into capabilities through

538 integration and reconfiguring its resources into organisational processes. Thus, the current

539 study identifies how the organisations can develop their resilience strategies based on their

540 internal processes such as collaboration efficiency, adopting digital technology and

541 humanitarian activities. The RSCs capabilities need to be strengthened for developing their

542 competitive advantage such as order fulfilment, inventory control, demand and supply

543 management, digitisation etc. to sustain during and post COVID situation.

544 The study has provided insights for retail organisations, suppliers and government

545 departments to manage their SCs more effectively and efficiently during the pandemic. The

546 study has employed advanced methods, FOCUM and BWM, to assess RSCs and identify the

547 appropriate solutions to survive during and after the pandemic. A focus is on the significant

548 determinants to enhance the performance of RSCs in a pandemic; this can support retailers

549 and suppliers to redesign their present strategies for the 'new normal' situation. The study has

550 made suggestions to organisations to adopt business strategies that consider and take actions

551 based on changing consumer behaviours due to a pandemic. This paper has identified the

552 significant determinants that drive the performance of RSCs and provide support for optimal

553 decision making. The study has contributed in determining the emerging significance of

554 order-fulfilment and digitization strategies in developing resilient RSCs during and post

555 COVID-19.

556

5.2 Implications of the Research

558 The COVID-19 pandemic has revealed the significance of collaborative partnerships with

559 third party service providers such as AI based or cloud-based management solutions to ensure

560 the handling of products efficiently and effectively. This study makes the following main

561 implications for managers and policy makers that can help RSCs to recover from the 562 pandemic and support SCs in the post pandemic world.

563 1) Developing a collaborative culture

564 The pre-pandemic market has been generally dominated by SCs that are transactional in 565 nature. However, such practices are not beneficial during a pandemic or in a post pandemic 566 environment. The findings suggest that SC partners need to be engaged in the sharing of data 567 and joint problem solving to enhance collaboration efficiency. The collaboration efficiency 
568 will help SC partners to share data in real-time that support scenario planning and 569 organisations to take more appropriate decisions.

2) Developing digital supply chains for building resilient organisations

571 The findings of this study are insightful for the managers. The study suggests that the

572 adoption of digital technology will help organisations to develop intelligent and resilient SCs

573 to enhance transparency and responsiveness. The transparency and responsiveness are the key

574 focus areas for developing resilient strategies during and post COVID-19 situation. DSNs

575 will enhance collaboration among SC partners and support them to assess the environment

576 and make them better prepared for the changing demands of consumer and markets. The

577 nature of current organisations in the market place is fragmented; this can be overcome with

578 the help of DSNs. SC partners should know what is being produced, moved and stored at any

579 particular time.

$580 \quad 3)$ Digitalisation strategy for flexible systems

581 Organisations need to develop agile SCs to fight against disruption; this can be made possible 582 through flexible systems that can adjust in real-time for managing a fluctuating capacity. Real

583 time data is a life saver for organisations and will support them during and post COVID-19.

584 The organisations should harness advance digital technologies that can capture relevant data

585 and develop prescriptive insights to help them to manage disruption. Apart from information

586 management, good working relationships with manufacturers will remain a cornerstone of

587 RSCs; flexibility to source from multiple suppliers will regain significance. Organisations

588 need to enhance the usage of emerging technologies such as IoT, blockchain, augmented

589 reality, robotics and big data analytics. These technologies will support organisations to 590 overcome the vulnerabilities of existing SCs caused by COVID-19.

591 4) People-are-first ethos

592 During the COVID-19 pandemic, delivery on time has become a key differentiator. With the 593 support from digital tools and collaborative planning, organisations will be able to fulfil 594 orders on time. The current study has revealed that order fulfilment is the need of the market 595 and the consumers as well. During COVID-19 the organisations have been challenged to 596 fulfil orders on time.

597 5) Align demand, capacity, supply and operations execution

598 The COVID-19 situation has witnessed the fluctuations in the demand and supply of various 599 products in the personal and healthcare range. The study has identified that inventory control 600 and demand-supply management are the determinants that drive the performance of the 601 RSCs. Thus, to deal with the uncertainty, the organisations need to adapt and modify their 
602 plans to continuously adjust demand, supply, capacity and operations execution. The 603 organisations that implement optimisation technologies can adapt and modify their plans 604 according to the changing needs.

605 6) Shift to e-commerce

606 A 'new normal' environment will consist of online orders, contactless and quick delivery 607 options. Most countries, including India, are living under restrictions; therefore RSCs need to 608 adapt strategies appropriately. RSCs need to adapt to this restricted living phase and prepare 609 themselves for the 'new normal'. COVID-19 is compelling organisations to develop resilient 610 RSCs that includes e-commerce that will be able to survive in any future emergency or 611 uncertain situation.

612

613 Those SCs focusing on order fulfilment, digitisation, inventory, demand and financial 614 stability are more effective during a pandemic as these strategies help organisations to 615 enhance their operational efficiency.

\section{Conclusion}

618 COVID-19 is a warning to retail organisations to re-plan and enhance readiness for an 619 uncertain future. The changing social, economic, environmental and political landscapes have 620 stressed the need for retailers to transform their existing business models. Order fulfilment 621 and demand forecasting are the key challenges exacerbated by COVID-19. Retailers who do 622 not plan for both these factors to meet customer expectation have placed themselves at high 623 risk of failure in the long term. This study has made an attempt to understand and analyse the 624 determinants of RSCs that may enhance business performance during and post COVID-19.

625 FOCUM has been used to establish the prominent determinants. A BWM is employed to 626 assess the business strategies of RSCs and to identify the most appropriate, given the 627 conditions caused by the pandemic. The dominant determinants highlighted are collaboration 628 efficiency, digital technologies adoption, partnership structure and communication quality. 629 These findings show that RSCs need full integration and collaboration to survive during and 630 post pandemic. Currently, the focus should be on order fulfilment, inventory control, demand 631 and financial stability.

632 Social distancing and the risks of being in public places are the new features that drive the

633 shift of consumers and organisations towards the adoption of e-commerce. This study has 634 opened a window of opportunity for retailers and suppliers to recognise changing consumer 635 behaviour; they can strategize the optimal human and machine ratio and then choose the most 
636 appropriate operating models accordingly. RSCs have to gain control of the on-going crisis 637 and should invest in building more resilient supply chains with advanced digital technologies.

638 There is a new normal that needs to be addressed.

639 This study has some limitations. Firstly, the study has applied methods for assessing RSCs

640 that are based on experts' opinions; hence the experts' bias may act as a limitation. The study 641 may be further empirically validated in future. The expert group has not included customers 642 and other stakeholders; the study can therefore be extended to include customers to enhance 643 the credibility of the expert group. Secondly, the impact of COVID-19 is global and hence 644 the study can be extended to other nations. The research framework has been developed in 645 the context of a single country; it may be tested further for different countries where 646 conditions are similar. Thirdly, the current study has consulted with experts from the retail 647 and supply chain industry of India and thus any outcome is region specific. More experts 648 from further afield can be added to validate the results of this research.

\section{References}

651 Abushaikha, I., Al-Weshah, G., Alsharairi, M., 2020. How do retail firms benefit from colocating in logistics-intensive clusters? A focus on the inbound supply function. The International Review of Retail, Distribution and Consumer Research, 30(1), 27-45.

Adivar, B., Hüseyinoğlu, I. Ö. Y., Christopher, M., 2019. A quantitative performance management framework for assessing omnichannel retail supply chains. Journal of Retailing and Consumer Services, 48, 257-269.

Albors-Garrigos, J., 2020. Barriers and enablers for innovation in the retail sector: Coinnovating with the customer. A case study in grocery retailing. Journal of Retailing and Consumer Services, 55, 102077.

Álvarez-Rodríguez, C., Martín-Gamboa, M., \& Iribarren, D., 2020a. Sensitivity of operational and environmental benchmarks of retail stores to decision-makers'

664 Álvarez-Rodríguez, C., Martín-Gamboa, M., Iribarren, D., 2020b. Sustainability-oriented preferences through Data Envelopment Analysis. Science of The Total Environment, 718, efficiency of retail supply chains: A combination of Life Cycle Assessment and dynamic network Data Envelopment Analysis. Science of The Total Environment, 705, 135977. relationships: Role of collaboration, sustainability, and technology. Sustainable Innovation, 47-58. 
670

671

672

673

674

675

676

677

678

679

680

681

682

683

684

685

686

687

688

689

690

691

692

693

694

695

696

697

698

699

700

701

702

Angulo-Baca, A., Bernal-Bazalar, M., Sotelo-Raffo, J., Raymundo-Ibañez, C.,Perez, M., 2020. Collaborative model based on ARIMA forecasting for reducing inventory costs at footwear SMEs. International Conference on Intelligent Human Systems Integration, $697-703$.

Ansari, Z. N., \& Kant, R., 2017. Exploring the framework development status for sustainability in supply chain management: A systematic literature synthesis and future research directions. Business Strategy and the Environment, 26(7), 873-892.

Azevedo, S. G., Govindan, K., Carvalho, H., Cruz-Machado, V., 2013. Ecosilient index to assess the greenness and resilience of the upstream automotive supply chain. Journal of Cleaner Production, 56, 131-146.

Baharmand, H., Comes, T., Lauras, M., 2019. Defining and measuring the network flexibility of humanitarian supply chains: insights from the 2015 Nepal earthquake. Annals of Operations Research, 283(1), 961-1000.

Balcik, B., Beamon, B. M., Krejci, C. C., Muramatsu, K. M., Ramirez, M., 2010. Coordination in humanitarian relief chains: Practices, challenges and opportunities. International Journal of Production Economics, 126(1), 22-34.

Basso, F., D'Amours, S., Rönnqvist, M., Weintraub, A., 2019. A survey on obstacles and difficulties of practical implementation of horizontal collaboration in logistics. International Transactions in Operational Research, 26(3), 775-793.

Beske, P., Land, A., Seuring, S., 2014. Sustainable supply chain management practices and dynamic capabilities in the food industry: A critical analysis of the literature. International Journal of Production Economics, 152, 131-143.

Börjeson, N., \& Boström, M., 2018. Towards reflexive responsibility in a textile supply chain. Business Strategy and the Environment, 27(2), 230-239.

Bozic, B., Kuppelwieser, V. G., 2019. Customer trust recovery: An alternative explanation. Journal of Retailing and Consumer Services, 49, 208-218.

Brandenburg, M., Gruchmann, T., Oelze, N., 2019. Sustainable supply chain managementA conceptual framework and future research perspectives. Sustainability, 11(24), 7239.

Bstieler, L., and Hemmert, M., 2015. The effectiveness of relational and contractual governance in new product development collaborations: Evidence from Korea. Technovation, 45, 29-39.

Cao, G. and Duan, Y., 2017. "How do top- and bottom-performing companies differ in using business analytics?", Journal of Enterprise Information Management, 30 (6),874-892. 
703

704

705

706

Carbone, V., Moatti, V., \& Vinzi, V. E., 2012. Mapping corporate responsibility and sustainable supply chains: an exploratory perspective. Business Strategy and the Environment, 21(7), 475-494.

Çelik, M., 2016. Network restoration and recovery in humanitarian operations: Framework, literature review, and research directions. Surveys in Operations Research and Management Science, 21(2), 47-61.

Chen, L., Zhao, X., Tang, O., Price, L., Zhang, S., Zhu, W., 2017. Supply chain collaboration for sustainability: A literature review and future research agenda. International Journal of Production Economics, 194, 73-87.

Chen, C., Gu, T., Cai, Y. and Yang, Y., 2019. "Impact of supply chain information sharing on performance of fashion enterprises: an empirical study using SEM", Journal of Enterprise Information Management, 32(6), 913-935.

Chi, M., Huang, R., \& George, J. F., 2020. Collaboration in demand-driven supply chain: Based on a perspective of governance and IT-business strategic alignment. International Journal of Information Management, 52, 102062.

Choi, T. M., \& Guo, S., 2020. Is a 'free lunch'a good lunch? The performance of zero wholesale price-based supply-chain contracts. European Journal of Operational Research, 285(1), 237-246.

Chtourou Ben Amar, N., and Ben Romdhane, R. (2019). Organizational culture and information systems strategic alignment: Exploring the influence through an empirical study from Tunisia. Journal of Enterprise Information Management, 33(1), 95-119.

Choudhary, D., Shankar, R., Dey, P. K., Chaudhary, H., Thakur, L. S. 2014. Benefits of retailer--supplier partnership initiatives under time-varying demand: a comparative analytical study. International Journal of Production Research, 52(14), 4279-4298.

Chowdhury, M. T., Sarkar, A., Paul, S. K., \& Moktadir, M. A., 2020. A case study on strategies to deal with the impacts of COVID-19 pandemic in the food and beverage industry. Operations Management Research, 1-13.

Christopher, M., Ryals, L. J., 2014. The supply chain becomes the demand chain. Journal of Business Logistics, 35(1), 29-35.

Cohen, M.J., 2020. Does the COVID-19 outbreak mark the onset of a sustainable consumption transition?, 1-3.

Cosenz, F., Rodrigues, V. P., \& Rosati, F., 2020. Dynamic business modeling for sustainability: Exploring a system dynamics perspective to develop sustainable business models. Business Strategy and the Environment, 29(2), 651-664. 
Cragg, T., \& McNamara, T., 2018. An ICT-based framework to improve global supply chain integration for final assembly SMES. Journal of Enterprise Information Management, 31(5),634-657.

Dahlmann, F., \& Roehrich, J. K., 2019. Sustainable supply chain management and partner engagement to manage climate change information. Business Strategy and the Environment, 28(8), 1632-1647.

Day, G. S., Schoemaker, P. J., 2016. Adapting to fast-changing markets and technologies. California Management Review, 58(4), 59-77.

Day, J. M., 2014. Fostering emergent resilience: the complex adaptive supply network of disaster relief. International Journal of Production Research, 52(7), 1970-1988.

Deep, S., Gajendran, T., Jefferies, M., 2019. A systematic review of 'enablers of collaboration' among the participants in construction projects. International Journal of Construction Management, 1-13

Deep, S., Gajendran, T., \& Jefferies, M., 2020. Factors influencing power and dependence for collaboration among construction project participants. Journal of Legal Affairs and Dispute Resolution in Engineering and Construction, 12(2).

Donthu, N., \& Gustafsson, A., 2020. Effects of COVID-19 on business and research. Journal of business research, 117, 284.

Ekinci, E., Baykasoğlu, A., 2019. Complexity and performance measurement for retail supply chains. Industrial Management \& Data Systems, 119(4), 719-742.

Fantazy, K., and Tipu, S. A. A., 2019. Exploring the relationships of the culture of competitiveness and knowledge development to sustainable supply chain management and organizational performance. Journal of Enterprise Information Management, 32(6), 936-963.

Fares, N., \& Lebbar, M., 2019. Optimisation of Fast Fashion Retail Supply Chain Processes: Overall Literature Review and Future Research Challenges. International Journal of Engineering Research in Africa, 45, 205-220.

Feizabadi, J., Gligor, D., Alibakhshi Motlagh, S., 2019. The triple-As supply chain competitive advantage. Benchmarking, 26(7), 2286-2317.

Frasquet, M., Dawson, J., Mollá, A., 2013. Post-entry internationalisation activity of retailers: An assessment of dynamic capabilities. Management Decision, 51(7), 1510-1527.

Frei, R., Jack, L., \& Krzyzaniak, S. A., 2020. Sustainable reverse supply chains and circular economy in multichannel retail returns. Business Strategy and the Environment 
770

771

772

773

774

775

776

Fuchs, C., Beck, D., Lienland, B. and Kellner, F., 2018. "The role of IT in automotive supplier supply chains", Journal of Enterprise Information Management, 31 (1), 64-88.

Gandhi, S. K., Sachdeva, A., \& Gupta, A., 2018. Operationalisation \& Measurement of Service Quality in Manufacturing Supply Chains: A Conceptual Framework. Pacific Business Review International, 10(11), 66-76.

Govindan, K., Malomfalean, A., 2019. A framework for evaluation of supply chain coordination by contracts under $\mathrm{O} 2 \mathrm{O}$ environment. International Journal of Production Economics, 215, 11-23.

Griffith, D. A., Boehmke, B., Bradley, R. V., Hazen, B. T., Johnson, A. W., 2019. Embedded analytics: improving decision support for humanitarian logistics operations. Annals of Operations Research, 283(1-2), 247-265.

Gustafsson, E., Jonsson, P., \& Holmström, J., 2019. Digital product fitting in retail supply chains: maturity levels and potential outcomes. Supply Chain Management: An International Journal (In Print)

Hingley, M., Lindgreen, A., \& Grant, D. B., 2015. Intermediaries in power-laden retail supply chains: An opportunity to improve buyer-supplier relationships and collaboration. Industrial Marketing Management, 50, 78-84.

Hofmann, E., \& Rutschmann, E., 2018. Big data analytics and demand forecasting in supply chains: a conceptual analysis. The International Journal of Logistics Management, 29(2), 739-766.

Holgado de Frutos, E., Trapero, J. R., Ramos, F., 2020. A literature review on operational decisions applied to collaborative supply chains. PloS one, 15(3), e0230152.

Holweg, M., Helo, P., 2014. Defining value chain architectures: Linking strategic value creation to operational supply chain design. International Journal of Production Economics, 147, 230-238.

Hollmann, R. L., Scavarda, L. F., Thomé, A. M. T., 2015. Collaborative planning, forecasting and replenishment: A literature review. International Journal of Productivity and Performance Management, 64(7), 971-993

Hübner, A., Holzapfel, A., Kuhn, H., 2016. Distribution systems in omni-channel retailing. Business Research, 9(2), 255-296.

Hughes, D. E., Richards, K. A., Calantone, R., Baldus, B., Spreng, R. A., 2019. Driving inrole and extra-role brand performance among retail frontline salespeople: Antecedents and the moderating role of customer orientation. Journal of Retailing, 95(2), 130-143. 
803

804

805

806

807

808

809

810

811

812

813

814

815

816

817

818

819

820

821

822

823

824

825

826

827

828

829

830

831

832

833

834

Iftikhar, R., \& Khan, M. S., 2020. Social Media Big Data Analytics for Demand Forecasting: Development and Case Implementation of an Innovative Framework. Journal of Global Information Management, 28(1), 103-120.

Ishfaq, R., \& Raja, U., 2018. Evaluation of order fulfilment options in retail supply chains. Decision Sciences, 49(3), 487-521.

Ishfaq, R., \& Bajwa, N., 2019. Profitability of online order fulfilment in multi-channel retailing. European Journal of Operational Research, 272(3), 1028-1040.

Ivanov, D., Sokolov, B., Kaeschel, J., 2010. A multi-structural framework for adaptive supply chain planning and operations control with structure dynamics considerations. European Journal of Operational Research, 200(2), 409-420.

Ivanov, D., Sethi, S., Dolgui, A., Sokolov, B., 2018. A survey on control theory applications to operational systems, supply chain management, and Industry 4.0. Annual Reviews in Control, 46, 134-147.

Ivanov, D., Dolgui, A., Das, A., Sokolov, B. 2019. Digital Supply Chain Twins: Managing the Ripple Effect, Resilience, and Disruption Risks by Data-Driven Optimisation, Simulation, and Visibility. Handbook of ripple effects in the supply chain, 309-332, Springer.

Iqbal, A., Latif, F., Marimon, F., Sahibzada, U.F. and Hussain, S. (2019), "From knowledge management to organizational performance: modelling the mediating role of innovation and intellectual capital in higher education", Journal of Enterprise Information Management, 32 (1), 36-59.

Jap, S. D., 1999. Pie-expansion efforts: Collaboration processes in buyer--supplier relationships. Journal of Marketing Research, 36(4), 461-475.

Kabuye, F., Kato, J., Akugizibwe, I., Bugambiro, N., 2019. Internal control systems, working capital management and financial performance of supermarkets. Cogent Business \& Management, 6(1).

Kamalaldin, A., Linde, L., Sjödin, D., Parida, V., 2020. Transforming provider-customer relationships in digital servitization: A relational view on digitalisation. Industrial Marketing Management. (In press)

KPMG. 2020. COVID-19 Surveillance challenges. Retrieved May 9, 2020, from https://home.kpmg/xx/en/blogs/home/posts/2020/04/surveillance-challenges-undercovid-19.html 
835 L'Hermitte, C., Tatham, P., Bowles, M.,Brooks, B., 2016. Developing organisational capabilities to support agility in humanitarian logistics. Journal of Humanitarian Logistics and Supply Chain Management, 6(1), 72-99.

Li, B., Jiang, Y., 2019. Impacts of returns policy under supplier encroachment with riskaverse retailer. Journal of Retailing and Consumer Services, 47, 104-115.

Li, J., Luo, X., Wang, Q., Zhou, W., 2020. Supply chain coordination through capacity reservation contract and quantity flexibility contract. Omega, 102195.

Li, K., Li, Y., Gu, Q., Ingersoll, A., 2019. Joint effects of remanufacturing channel design and after-sales service pricing: an analytical study. International Journal of Production Research, 57(4), 1066-1081.

Liu, S., Lin, J., Hayes, K. A., 2010. An agile and diversified supply chain: reducing operational risks. Competitiveness review: An international business journal, 20(3), 222234.

Liu, X., Hodgkinson, I. R., Chuang, F.-M., 2014. Foreign competition, domestic knowledge base and innovation activities: Evidence from Chinese high-tech industries. Research Policy, 43(2), 414-422.

Liu, Y., 2014. Big data and predictive business analytics. The Journal of Business Forecasting, 33(4), 40.

Liu, Y., Wang, D. D., Xu, Q., 2020. A supply chain coordination mechanism with suppliers' effort performance level and fairness concern. Journal of Retailing and Consumer Services, 53, 101950.

Lohmer, J., Bugert, N., \& Lasch, R. (2020). Analysis of resilience strategies and ripple effect in blockchain-coordinated supply chains: An agent-based simulation study. International journal of production economics, 228, 107882.

Low, J. S. C., and Ng, Y. T., 2018. Improving the economic performance of remanufacturing systems through flexible design strategies: a case study based on remanufacturing laptop computers for the Cambodian market. Business Strategy and the Environment, 27(4), 503-527.

Madsen, S. M., \& Petermans, A., 2020. Exploring the system of digitised retail designflattening the ontology. Journal of Retailing and Consumer Services, 54, 102053.

Martin, J., Hofmann, E., 2019. Towards a framework for supply chain finance for the supply side. Journal of Purchasing and Supply Management, 25(2), 157-171. 
McKinsey. 2020, April 13. McKinsey. Retrieved May 9, 2020, from COVID-19: Implications for business: https://www.mckinsey.com/business-functions/risk/ourinsights/covid-19-implications-for-business.

Mena, C., Bourlakis, M., Hübner, A., Wollenburg, J., Holzapfel, A., 2016. Retail logistics in the transition from multi-channel to omni-channel. International Journal of Physical Distribution \& Logistics Management, 46(6/7), 562-583.

Mendes Jr, P., Leal, J. E., Thomé, A. M. T., 2016. A maturity model for demand-driven supply chains in the consumer product goods industry. International Journal of Production Economics, 179, 153-165.

MoSPI. 2020. Ministry of Statistics and Programme Implementation. Retrieved May 09, 2020,fromhttp://www.mospi.nic.in/sites/default/files/press_release/Press_Note_NAD_31 012020.pdf

Naik, G. and Suresh, D. N., 2018. Challenges of creating sustainable agri-retail supply chains. IIMB management review, 30(3), 270-282.

Nguyen, H., \& Harrison, N., 2019. Leveraging customer knowledge to enhance process innovation. Business Process Management Journal, 25(2), 307-322.

Obeng, E. 2019. Bullseye: An argument for effectively managing retail stakeholder relationships. Journal of Retailing and Consumer Services, 49, 327-335.

Panahifar, F., Byrne, P.J., Salam, M.A. and Heavey, C., 2018. "Supply chain collaboration and firm's performance: the critical role of information sharing and trust", Journal of Enterprise Information Management, 31(3), 358-379.

Panahifar, F., Shokouhyar, S., 2019. An interpretive structural modelling of enablers for collaborative planning, forecasting and replenishment implementation in high-tech industries. International Journal of Information and Decision Sciences, 11(1), 55-72

894 Pankowska, M., 2019. Information technology outsourcing chain: Literature review and implications for development of distributed coordination. Sustainability,11(5), 1460.

Parimi, S., Chakraborty, S., 2020. Linking Green Supply Chain Management, Co-creation, and Sustainability: Empirical Revisit in Indian Manufacturing Sector Context. Smart Innovation, Systems and Technologies, 141, 617-629. 
899 Peinkofer, S. T., Esper, T. L., Smith, R. J., Williams, B. D., 2019. Assessing the impact of drop-shipping fulfilment operations on the upstream supply chain. International Journal of Production Research, 57(11), 3598-3621.

902 Pereira, M. M., and Frazzon, E. M., 2020. A data-driven approach to adaptive synchronization of demand and supply in omni-channel retail supply chains. International Journal of Information Management, 102165.

Prince, M., Kwak, L., Priporas, C. V., 2019. The Diogenes Effect in retail buyer information processing. Journal of Retailing and Consumer Services, 49, 164-172.

Pulles, N. J., Hartman, P., 2017. Likeability and its effect on outcomes of interpersonal interaction. Industrial Marketing Management, 66, 56-63.

Ransikarbum, K., Mason, S. J., 2016. Multiple-objective analysis of integrated relief supply and network restoration in humanitarian logistics operations. International Journal of Production Research, 54(1), 49-68.

Rao, S., Griffis, S. E., Goldsby, T. J., 2011. Failure to deliver? Linking online order fulfilment glitches with future purchase behavior. Journal of Operations Management, 29(7-8), 692-703.

Rezaei, J., Nispeling, T., Sarkis, J., Tavasszy, L., 2016. A supplier selection life cycle approach integrating traditional and environmental criteria using the best worst method. Journal of Cleaner Production, 135, 577-588.

Roggeveen, A. L., Sethuraman, R., 2020. How the COVID Pandemic May Change the World of Retailing. Journal of Retailing (In print)

Ryu, M.H., Cho, Y., Lee, D., 2019. Should small-scale online retailers diversify distribution channels into offline channels? Focused on the clothing and fashion industry. Journal of and Retailing Consumer services, 47, 74-77.

Sandberg, E., Jafari, H., 2018. Retail supply chain responsiveness. International Journal of Productivity and Performance Management 67(9), 1977- 1993

Saghiri, S., Wilding, R., Mena, C., Bourlakis, M., 2017. Toward a three-dimensional framework for omni-channel. Journal of Business Research, 77, 53-67.

Sajjad, A., Eweje, G., \& Tappin, D., 2020. Managerial perspectives on drivers for and

930 Sarkis, J., Cohen, M.J., Dewick, P. and Schröder, P., 2020. A brave new world: Lessons from 931 the COVID-19 pandemic for transitioning to sustainable supply and production. Resources, Conservation, and Recycling. 159, 104894. 
933 Scholten, K., \& Schilder, S., 2015. The role of collaboration in supply chain resilience. Supply Chain Management-An International Journal, 20(4), 471-484.

935 Sener, A., Barut, M., Oztekin, A., Avcilar, M. Y., Yildirim, M. B., 2019. The role of 936 information usage in a retail supply chain: A causal data mining and analytical modeling approach. Journal of Business Research, 99, 87-104.

Selviaridis, K., Norrman, A., 2014. Performance-based contracting in service supply chains: a service provider risk perspective. Supply Chain Management: An International Journal, 19(2), 153-172

Sillanpää, V., Liesiö, J., 2018. Forecasting replenishment orders in retail: Value of modelling low and intermittent consumer demand with distributions. International Journal of Production Research, 56(12), 4168-41

Simchi-Levi, D., Kaminsky, P., Simchi-Levi, E., \& Shankar, R. 2008. Designing and managing the supply chain: concepts, strategies and case studies. Tata McGraw-Hill Education.

Singh, J., Arnold, T., Brady, M., Brown, T., 2019. Synergies at the intersection of retailing and organisational frontlines research. Journal of Retailing, 95, 90-93.

Song, M.-L., Fisher, R., Wang, J.-L., Cui, L.-B. (2018). Environmental performance evaluation with big data: Theories and methods. Annals of Operations Research, 270(12), 459-472.

Sorkun, M. F., Hüseyinoğlu, I. Ö. Y., \& Börühan, G., 2020. Omni-channel capability and customer satisfaction: mediating roles of flexibility and operational logistics service quality. International Journal of Retail \& Distribution Management. (in Print).

Stević, Ž., Pamučar, D., Subotić, M., Antuchevičiene, J., Zavadskas, E. K., 2018. The location selection for roundabout construction using Rough BWM-Rough WASPAS approach based on a new Rough Hamy aggregator. Sustainability, 10(8), 2817.

Stević, Ž., \& Brković, N. 2020. A Novel Integrated FUCOM-MARCOS Model for Evaluation of Human Resources in a Transport Company. Logistics, 4(1), 4.

Sukati, I., Hamid, A. B., Baharun, R.,Yusoff, R. M., 2012. The study of supply chain management strategy and practices on supply chain performance. Procedia-Social and Behavioral Sciences, 40, 225-233.

Verdouw, C. N., Beulens, A. J. M., Trienekens, J. H., \& Wolfert, J., 2010. Process modelling in demand-driven supply chains: A reference model for the fruit industry. Computers and Electronics in Agriculture, 73(2), 174-187. 
966 Wankmüller, C., \& Reiner, G., 2020. Coordination, cooperation and collaboration in relief 967 supply chain management. Journal of Business Economics, 90 (2), 239-276.

968 World Trade Organisation (WTO), 2020. Trade set to plunge as COVID-19 pandemic upends global economy. Press Release April 8. https://www.wto.org/english/news e/pres20_e/pr855_e.htm.

971 Xu, X., Jackson, J. E., 2019. Investigating the influential factors of return channel loyalty in 972 omni-channel retailing. International Journal of Production Economics, 216, 118-132.

973 Youn, C., Kim, S. Y., Lee, Y., Choo, H. J., Jang, S., \& Jang, J. I. (2017). Measuring retailers' $974 \quad$ sustainable development. Business strategy and the environment, 26(3), 385-398.

975 Young, C. W., Russell, S. V., Robinson, C. A., \& Chintakayala, P. K., 2018. Sustainable 976 retailing-influencing consumer behaviour on food waste. Business Strategy and the 977 Environment, 27(1), 1-15.

\section{Appendices}

\section{Appendix I}

981 Details of determinants

\begin{tabular}{|c|c|c|}
\hline Cri & nplied meaning & mes \\
\hline $\begin{array}{l}\text { Collaboration } \\
\text { efficiency }\left(\mathrm{C}_{1}\right) \\
\text { (Collaborative } \\
\text { Planning, Forecasting } \\
\text { and replenishment, } \\
\text { Resource sharing, } \\
\text { Network resources, } \\
\text { Co-creation) }\end{array}$ & $\begin{array}{l}\text { The collaboration among RSC } \\
\text { partners for predicting demand and } \\
\text { supply management }\end{array}$ & $\begin{array}{l}\text { Enhances resilience of RSCs that may } \\
\text { help survival in post pandemic } \\
\text { situation. External sources provide } \\
\text { strategic opportunities to RSCs to take } \\
\text { strategic actions } \\
\text { Collaborative innovation brings value } \\
\text { added products that may fulfil the } \\
\text { needs of customers during difficult } \\
\text { times }\end{array}$ \\
\hline $\begin{array}{l}\text { Partnership structure } \\
\left(\mathrm{C}_{2}\right) \\
\text { (Including } \\
\text { Flexibility, Visibility, } \\
\text { governance } \\
\text { structures) }\end{array}$ & $\begin{array}{l}\text { The structure of partnerships } \\
\text { among retailers and suppliers to } \\
\text { enhance the business performance }\end{array}$ & $\begin{array}{l}\text { It improves information sharing, } \\
\text { integration, transparency and flexibility } \\
\text { among partners in RSCs. It helps a } \\
\text { retail organisation to quickly respond } \\
\text { to the uncertain environment }\end{array}$ \\
\hline $\begin{array}{l}\text { Adoption of Digital } \\
\text { Technologies } \\
\left(\mathrm{C}_{3}\right)\end{array}$ & $\begin{array}{l}\text { Big Data Analytics (BDA), } \\
\text { Artificial intelligence, Internet of } \\
\text { things etc. adoption in retail } \\
\text { organisations to enhance the } \\
\text { efficiency of business operations. }\end{array}$ & $\begin{array}{l}\text { Online order and delivery management } \\
\text { accelerates order fulfilment processes } \\
\text { and enhances efficiency. BDA provides } \\
\text { insights for decision making to deal } \\
\text { with uncertain conditions } \\
\text { Saves cost and time }\end{array}$ \\
\hline $\begin{array}{l}\text { Humanitarian relief } \\
\text { operations }\left(\mathrm{C}_{4}\right)\end{array}$ & $\begin{array}{l}\text { The emergency operations } \\
\text { performed by retail organisations } \\
\text { during uncertainty. }\end{array}$ & $\begin{array}{l}\text { Reducing product complexity and } \\
\text { delivering product flexibility results in } \\
\text { reducing the cost. }\end{array}$ \\
\hline
\end{tabular}




\begin{tabular}{|c|c|c|}
\hline & & $\begin{array}{l}\text { More options to make delivery helps } \\
\text { retailers to avoid flow disruptions }\end{array}$ \\
\hline $\begin{array}{l}\text { Operational and } \\
\text { dynamic capabilities } \\
\left(\mathrm{C}_{5}\right)\end{array}$ & $\begin{array}{l}\text { Capabilities to develop competitive } \\
\text { advantages for retail organisations }\end{array}$ & $\begin{array}{l}\text { Re-designing may support in risk } \\
\text { reduction and developing competitive } \\
\text { advantage for resilient supply chains } \\
\text { during and post COVID-19 }\end{array}$ \\
\hline $\begin{array}{l}\text { Information and } \\
\text { Communication } \\
\text { quality }\left(\mathrm{C}_{6}\right)\end{array}$ & $\begin{array}{l}\text { Flow of information and } \\
\text { communication between } \\
\text { partners among RSCs }\end{array}$ & $\begin{array}{l}\text { Internal communication develops } \\
\text { capabilities between retailers, suppliers } \\
\text { and customers }\end{array}$ \\
\hline
\end{tabular}

- Steps to fill the Table I A

1. Arrange the criteria according to their preference.

2. Provide values to each determinant on a scale 1 to 9

Table I-A: Preference rating of determinants

\begin{tabular}{l|l|l|l|l|l|l}
\hline Criteria & $\mathrm{C}_{1}$ & $\mathrm{C}_{2}$ & $\mathrm{C}_{3}$ & $\mathrm{C}_{4}$ & $\mathrm{C}_{5}$ & $\mathrm{C}_{6}$ \\
\hline & & & & & & \\
\hline
\end{tabular}

\section{Details of Business Strategies}

\begin{tabular}{l|l}
\hline Alternatives & Performance outcomes \\
\hline Digitisation strategy $\left(\mathrm{BS}_{1}\right)$ & $\begin{array}{l}\text { Digital technology adoption to provide customer services online } \\
\text { and handle multiple requests at one time }\end{array}$ \\
\hline Omni-channel strategy $\left(\mathrm{BS}_{2}\right)$ & $\begin{array}{l}\text { Omni-channel supply chains provide one-touch integration } \\
\text { across all channels to provide unified experience. }\end{array}$ \\
\hline $\begin{array}{l}\text { Diversification and offshoring } \\
\text { strategy }\left(\mathrm{BS}_{3}\right)\end{array}$ & $\begin{array}{l}\text { Extension of the portfolio of services including core and non- } \\
\text { core services }\end{array}$ \\
\hline $\begin{array}{l}\text { Order fulfilment and } \\
\text { optimisation strategy }\left(\mathrm{BS}_{4}\right)\end{array}$ & $\begin{array}{l}\text { Exhausting local partners to jointly work for pickup and delivery } \\
\text { items }\end{array}$ \\
\hline $\begin{array}{l}\text { Inventory control strategy }\left(\mathrm{BS}_{5}\right) \\
\text { The ability to predict and manage demand. Demand forecasting } \\
\text { and inventory control need to be considered to prevent stock-out } \\
\text { situations. }\end{array}$ \\
\hline $\begin{array}{l}\text { Distribution network strategy } \\
\left(\mathrm{BS}_{6}\right)\end{array}$ & $\begin{array}{l}\text { Retailers are extending their distribution networks to meet } \\
\text { demands of customers and enhance their survivability }\end{array}$ \\
\hline $\begin{array}{l}\text { Revenue management strategy } \\
\left(\mathrm{BS}_{7}\right)\end{array}$ & $\begin{array}{l}\text { Financial stability under a variety of different scenarios. } \\
\text { Retailers are closely looking at liquidity and working capital }\end{array}$ \\
\hline $\begin{array}{l}\text { Customer Relationship } \\
\text { Management (CRM) strategy } \\
\left(\mathrm{BS}_{8}\right)\end{array}$ & Building and maintaining trust among consumers. \\
\hline $\begin{array}{l}\text { Dynamic pricing strategy } \\
\left(\mathrm{BS}_{9}\right)\end{array}$ & $\begin{array}{l}\text { Competitive pricing as demand increases in uncertain conditions. } \\
\text { Sentiment analysis can help in effective pricing. }\end{array}$ \\
\hline
\end{tabular}


Table I-B: Preference rating of business strategies

\begin{tabular}{l|l|l|l|l|l|l|l|l|l}
\hline Alternative=9 & $\mathbf{B S}_{1}$ & $\mathbf{B S}_{2}$ & $\mathbf{B S}_{3}$ & $\mathbf{B S}_{4}$ & $\mathbf{B S}_{5}$ & $\mathbf{B S}_{6}$ & $\mathbf{B S}_{7}$ & $\mathbf{B S}_{\mathbf{8}}$ & $\mathbf{B S}_{9}$ \\
\hline & & & & & & & & & \\
\hline
\end{tabular}

1000

1001

1002

1003

1004

1005

1006

1007

1008

1009

1010

1011

- Select the best alternative

- Select the worst alternative

- Compare each alternative relative to best and worst alternatives and rate in Table I-C and I$\mathrm{D}$

Table I-C: Comparison of alternatives (Best to other)

\begin{tabular}{l|l|l|l|l|l|l|l|l|l|}
\hline Best to other & $\mathbf{B S}_{1}$ & $\mathbf{B S}_{2}$ & $\mathbf{B S}_{3}$ & $\mathbf{B S}_{4}$ & $\mathbf{B S}_{5}$ & $\mathbf{B S}_{6}$ & $\mathbf{B S}_{7}$ & $\mathbf{B S}_{8}$ & $\mathbf{B S}_{9}$ \\
\hline $\begin{array}{l}\text { Best Criteria } \\
\text { (ranking 1-9) }\end{array}$ & & & & & & & & & \\
\hline
\end{tabular}

Table I-D: Comparison of alternatives (Others to the Worst)

\begin{tabular}{c|c}
\hline Others to the Worst & Rank \\
\hline $\mathrm{BS}_{1}$ & \\
\hline $\mathrm{BS}_{2}$ & \\
\hline $\mathrm{BS}_{3}$ & \\
\hline $\mathrm{BS}_{4}$ & \\
\hline $\mathrm{BS}_{5}$ & \\
\hline $\mathrm{BS}_{6}$ & \\
\hline $\mathrm{BS}_{7}$ & \\
\hline $\mathrm{BS}_{8}$ & \\
\hline $\mathrm{BS}_{9}$ &
\end{tabular}

\section{Appendix II}

Table II-A: Expert responses for determinants (criteria)

\begin{tabular}{c|c|c|c|c|c|c}
\hline Experts & $\mathbf{C}_{\boldsymbol{1}}$ & $\mathbf{C}_{\boldsymbol{3}}$ & $\mathbf{C}_{\boldsymbol{4}}$ & $\mathbf{C}_{\mathbf{5}}$ & $\mathbf{C}_{\mathbf{2}}$ & $\mathbf{C}_{\mathbf{6}}$ \\
\hline E1 & 1.00 & 2.50 & 3.50 & 4.00 & 5.00 & 6.00 \\
\hline E2 & 1.00 & 2.00 & 3.50 & 4.50 & 6.00 & 7.00 \\
\hline E3 & 1.00 & 2.60 & 5.00 & 3.00 & 6.50 & 8.00 \\
\hline E4 & 1.00 & 3.50 & 2.40 & 4.00 & 4.50 & 7.00 \\
\hline E5 & 1.00 & 2.00 & 3.00 & 5.00 & 7.00 & 9.00 \\
\hline E6 & 1.00 & 3.00 & 2.00 & 3.00 & 7.00 & 9.00 \\
\hline E7 & 1.00 & 2.50 & 2.00 & 5.00 & 5.00 & 7.00 \\
\hline E8 & 1.00 & 2.00 & 4.00 & 5.00 & 7.00 & 8.00 \\
\hline E9 & 1.00 & 2.50 & 3.00 & 4.00 & 6.00 & 6.00 \\
\hline E10 & 1.00 & 3.00 & 4.00 & 3.00 & 7.00 & 8.00 \\
\hline
\end{tabular}




\begin{tabular}{c|c|c|c|c|c|c}
\hline E11 & 1.00 & 4.00 & 3.00 & 5.00 & 5.50 & 7.00 \\
\hline E12 & 1.00 & 2.00 & 4.00 & 4.00 & 7.00 & 8.00 \\
\hline E13 & 1.00 & 3.00 & 3.00 & 5.00 & 6.00 & 8.00 \\
\hline E14 & 1.00 & 3.50 & 5.00 & 5.00 & 4.00 & 7.50 \\
\hline E15 & 1.00 & 2.50 & 2.00 & 3.00 & 4.50 & 7.00 \\
\hline E16 & 1.00 & 3.00 & 4.00 & 3.00 & 7.00 & 6.00 \\
\hline E17 & 1.00 & 2.00 & 2.00 & 5.00 & 6.00 & 8.00 \\
\hline E18 & 1.00 & 3.00 & 4.00 & 4.00 & 7.00 & 6.00 \\
\hline E19 & 1.00 & 3.00 & 3.50 & 3.00 & 5.00 & 7.00 \\
\hline E20 & 1.00 & 3.50 & 3.00 & 5.00 & 7.00 & 8.00 \\
\hline E21 & 1.00 & 2.50 & 4.00 & 6.00 & 6.00 & 7.00 \\
\hline E22 & 1.00 & 3.00 & 4.00 & 4.00 & 6.50 & 8.00 \\
\hline & & & & &
\end{tabular}

1020 Table II- B: Comparison of Business Strategy Alternatives using BWM solver

\begin{tabular}{c|c|c|c|c|c|c|c|c|c}
\hline Experts & BS $_{\mathbf{1}}$ & $\mathbf{B S}_{\mathbf{2}}$ & $\mathbf{B S}_{\mathbf{3}}$ & $\mathbf{B S}_{\mathbf{4}}$ & $\mathbf{B S}_{\mathbf{5}}$ & $\mathbf{B S}_{\mathbf{6}}$ & $\mathbf{B S}_{\mathbf{7}}$ & $\mathbf{B S}_{\mathbf{8}}$ & $\mathbf{B S}_{\mathbf{9}}$ \\
\hline E1 & 0.2516 & 0.1380 & 0.1055 & 0.0974 & 0.0974 & 0.0731 & 0.1461 & 0.0584 & 0.0325 \\
\hline E2 & 0.2456 & 0.1347 & 0.0951 & 0.0951 & 0.0951 & 0.1030 & 0.1426 & 0.0571 & 0.0317 \\
\hline E3 & 0.2635 & 0.1419 & 0.0932 & 0.0770 & 0.1027 & 0.1027 & 0.0770 & 0.1176 & 0.0243 \\
\hline E4 & 0.2641 & 0.1094 & 0.1086 & 0.1642 & 0.1094 & 0.1094 & 0.0657 & 0.0469 & 0.0222 \\
\hline E5 & 0.0237 & 0.2818 & 0.1159 & 0.1751 & 0.1167 & 0.1167 & 0.0700 & 0.0500 & 0.0500 \\
\hline E6 & 0.1163 & 0.2952 & 0.0398 & 0.1163 & 0.1431 & 0.1193 & 0.0716 & 0.0716 & 0.0268 \\
\hline E7 & 0.1267 & 0.0171 & 0.2291 & 0.1097 & 0.1267 & 0.1015 & 0.1267 & 0.0609 & 0.1015 \\
\hline E8 & 0.1297 & 0.0243 & 0.2676 & 0.1054 & 0.1297 & 0.0649 & 0.1081 & 0.0649 & 0.1054 \\
\hline E9 & 0.1305 & 0.0384 & 0.0864 & 0.2994 & 0.1305 & 0.0691 & 0.1152 & 0.0282 & 0.1024 \\
\hline E10 & 0.1143 & 0.0381 & 0.1167 & 0.2882 & 0.1143 & 0.1143 & 0.0686 & 0.0310 & 0.1143 \\
\hline E11 & 0.1180 & 0.0363 & 0.1180 & 0.2813 & 0.1543 & 0.0817 & 0.0653 & 0.0363 & 0.1089 \\
\hline E12 & 0.1489 & 0.0350 & 0.1138 & 0.2715 & 0.1489 & 0.0788 & 0.0350 & 0.0630 & 0.1051 \\
\hline E13 & 0.1414 & 0.0749 & 0.1082 & 0.1498 & 0.2579 & 0.0749 & 0.0333 & 0.0599 & 0.0998 \\
\hline E14 & 0.0948 & 0.0711 & 0.1280 & 0.1422 & 0.2417 & 0.0995 & 0.0284 & 0.0995 & 0.0948 \\
\hline E15 & 0.0813 & 0.1084 & 0.1129 & 0.1626 & 0.2755 & 0.0650 & 0.0316 & 0.0813 & 0.0813 \\
\hline E16 & 0.0811 & 0.1081 & 0.1622 & 0.1622 & 0.0270 & 0.1892 & 0.1081 & 0.0811 & 0.0811 \\
\hline E17 & 0.1393 & 0.0984 & 0.0984 & 0.0738 & 0.0328 & 0.2541 & 0.0984 & 0.1066 & 0.0984 \\
\hline E18 & 0.1282 & 0.1026 & 0.1026 & 0.0769 & 0.0256 & 0.1026 & 0.2564 & 0.1026 & 0.1026 \\
\hline E19 & 0.1250 & 0.1000 & 0.1000 & 0.0750 & 0.1250 & 0.0250 & 0.2500 & 0.1000 & 0.1000 \\
\hline E20 & 0.1229 & 0.0975 & 0.0975 & 0.0805 & 0.1229 & 0.0254 & 0.0805 & 0.2754 & 0.0975 \\
\hline E21 & 0.0997 & 0.0748 & 0.0748 & 0.0997 & 0.1365 & 0.0262 & 0.0840 & 0.2677 & 0.1365 \\
\hline E22 & 0.1045 & 0.0784 & 0.0255 & 0.1045 & 0.1439 & 0.0348 & 0.0929 & 0.2716 & 0.1439 \\
\hline & & & & & & &
\end{tabular}

1021 